This PDF is a selection from a published volume from the National Bureau of Economic Research

Volume Title: Managing Currency Crises in Emerging Markets

Volume Author/Editor: Michael P. Dooley and Jeffrey A.

Frankel, editors

Volume Publisher: University of Chicago Press

Volume ISBN: 0-226-15540-4

Volume URL: http://www.nber.org/books/dool03-1

Conference Date: March 28-31, 2001

Publication Date: January 2003

Title: Recovery and Sustainability in East Asia

Author: Yung Chul Park, Jong-Wha Lee

URL: http://www.nber.org/chapters/c9654 


\title{
Recovery and Sustainability in East Asia
}

\author{
Yung Chul Park and Jong-Wha Lee
}

\subsection{Introduction}

Over the three years since the crisis broke out in 1997, the five Asian countries-Indonesia, Korea, Thailand, Malaysia, and the Philippinesmanaged impressive recoveries. The recoveries were faster than expected by anyone. The economies started to bottom out in the second half of 1998 . The rebounding of the growth rate in 1999 was no less drastic than its freefall. In Korea, for example, the growth rates showed a turnaround from -6.7 percent in 1998 to 10.7 percent in 1999.

The purpose of this paper is to make an assessment of this speedy adjustment from the crisis in East Asia. In particular, we analyze the macroeconomic adjustment process of the East Asian currency crisis in a broad international perspective. First, we assess the impacts of the crisis on gross domestic product (GDP) growth using a cross-country data set, which compiled all currency crisis episodes over the period from 1970 to 1995. From these cross-country data, we draw some stylized facts about the adjustment of key macroeconomic variables during the crisis. Then we investigate the critical factors that determine the adjustment process.

Our analysis of cross-country patterns shows that GDP growth rates drop with the eruption of a crisis but then recover quickly to the precrisis level in two or three years, showing a V-pattern of adjustment. Thereafter, the GDP growth rates tend to rise slightly above the precrisis levels, but then

Yung Chul Park is a professor of economics at Korea University. Jong-Wha Lee is a professor of economics at Korea University.

The authors thank Robert Barro, Richard Portes, and conference participants for their helpful comments on an earlier draft. Si-Yeon Lee and Do-Won Kwak provided able research assistance. 
they subside to a more sustainable level. We also compare the adjustment patterns of GDP growth rates between two subgroups of the currency crisis episodes, one with conditional financial assistance from the International Monetary Fund (IMF) and the other without. We find that the adjustment process was much sharper in the group of the crisis episodes with the IMF program compared to those without. That is, in the IMF-program countries, GDP growth rates start to fall precipitously even before the eruption of a crisis but then recover to their precrisis level more quickly in two years.

The macroeconomic adjustment process in East Asia is in general consistent with these stylized patterns. However, the degree of initial contraction and following recovery has been far greater in East Asia than what the cross-country evidence predicts. This paper tries to make an evaluation of what factors contributed to the sharper contraction and the quicker recovery in East Asia compared with the cross-country patterns.

As we will discuss in section 9.3, we believe that a large number of internal and external factors are responsible for the deeper crisis and the quicker recovery in East Asia. The origin and the nature of the shock, the initial conditions, the development of external environments, and the stabilization and structural adjustment policies taken must have a significant consequence on the adjustment path, as they did in the eruption of the crisis. From cross-country regressions based on the sample of previous crisis episodes, we find that depreciation of exchange rate, expansionary macroeconomic policies, and favorable global environments are the critical determinants of the postcrisis recovery. In the regression, the financial assistance from the IMF is found to have no independent impact on the recovery process.

We find that the quick recoveries in East Asia have been driven largely by the accommodating macroeconomic policies, favorable external environments, and more export-oriented structure. Korea, Malaysia, and Thailand shifted to a relaxation of monetary and fiscal policies by the second half of 1998 , and then their economy took off. The sharp real depreciation of currency must have a bigger impact on more open Asian economies. Favorable external development also helped the quick improvement in East Asian exports. In this sense, the East Asian process of adjustment is not much different from the stylized pattern from the previous currency crisis episodes over the period from 1970 to 1995 . However, the stylized pattern of adjustment cannot explain why the crisis was more severe and the recovery much faster than what was expected from the previous experiences of crisis. This paper argues that the sharper adjustment pattern in East Asia is due to the severe liquidity crisis that was triggered by investors' panic and then amplified by the weak corporate and bank balance sheet.

The stylized pattern of real GDP growth from the cross-country episodes displays that the crisis-hit countries can recover their precrisis or noncrisis average growth rate in three years after the crisis. Hence, it raises a question 
of whether the East Asian economies will be able to return to the precrisis trend rate of growth.

Although the financial crisis of 1997 abruptly brought a halt to Asia's period of robust growth, there was little in Asia's fundamentals that inevitably led to the crisis. This paper discusses the long-term prospects for growth in East Asia. From the cross-country regressions, we find that there is no evidence of a direct impact of a currency crisis on long-run growth. This suggests that, with a return to the core policies that resulted in rapid growth, the East Asian economies can again return to sustained growth.

The paper is organized as follows. Section 9.2 discusses the methodology for our cross-country analysis and presents central features in the macroeconomic adjustments of the crisis-hit countries. Then, using regression analysis based on the cross-country data, we assess the factors that can explain the behaviors of GDP growth rates during the crisis. Section 9.3 reviews the recent recoveries in East Asia and compares them with the stylized patterns from the cross-country analysis. We analyze the driving forces of the faster recovery in East Asia. Section 9.4 discusses the issue of the sustainability of the current recovery. Concluding remarks are found in the final section.

\subsection{Cross-Country Patterns of Adjustment to Currency Crisis}

\subsubsection{Data}

In order to assess the postcrisis adjustment of the crisis-hit countries, one needs first to define a currency crisis. Several alternative indicators and methods have been used in the literature to identify the year when a crisis erupted in each country. Frankel and Rose (1996) and Milesi-Ferreti and Razin (1998) used the nominal depreciation rate of the currency. Sachs, Tornell, and Velasco (1996), Radelet and Sachs (1998), and Kaminsky and Reinhart (1999) combined the depreciation rate with additional indicators such as losses in foreign reserves, increase in the interest rate, and reversal in capital accounts to identify the crisis.

Each definition still has its own limitations. A large-scale depreciation can occur in an orderly manner without a speculative attack. Identifying unsuccessful speculative attacks is a difficult task. Reliable data on reserves and interest rates in developing countries are often unavailable. Reserves or interest rates can change irrespective of an attack. Lee and Rhee (2002) suggested an alternative measure based on the initiation of an IMF stabilization program. However, countries often receive the IMF program after a crisis breaks out or without a currency crisis. Governments may sign an IMF agreement not necessarily because they need foreign exchange, but because they want austerity conditions to be imposed (Przeworski and Vreeland 2000). 
Because the purpose of this paper is not to improve the measure of a currency crisis, we use the conventional nominal depreciation rate of the currency as a benchmark measure. However, in contrast to Frankel and Rose (1996), we use quarterly data, instead of annual data, to define a currency crisis. That is, based on quarterly data, a country is judged to have a currency crisis in the specific year when it has a nominal depreciation of currency of at least 25 percent in any quarter of the year and the depreciation rate exceeds the previous quarter's change in the exchange rate by a margin of at least 10 percent. Thus, our definition captures the incidences of currency crises that were severe but short-lived, perhaps due to successful interventions in the foreign exchange market. During the period from 1970 to 1997, the total number of currency crises was 260 . We use a window of plus/minus two years to identify an independent crisis. That is, if there was a precedent crisis within two years before a crisis, we count the latter as a consecutive crisis, not an independent one. This procedure yields a total of 192 currency crisis episodes. ${ }^{1}$

Then, we divide all crisis episodes into two groups based on whether the crisis-hit countries entered into an IMF program or not. We have compiled data on all types of IMF programs that include standby arrangements, Extended Fund Facility (EFF) arrangements, Structural Adjustment Facility (SAF), and Enhanced Structural Adjustment Facility (ESAF) over the period from 1970 to $1997 .{ }^{2}$ The program is identified by the year when the loans are approved. Thus, if a country received financial assistance from the IMF during the year of, or one year after, the currency crisis, we consider it a case of a currency crisis with the IMF program. Note that the decision on participation in the IMF program following a currency crisis can be determined endogenously by various factors. A country may enter into agreements with the IMF when it faces a more severe foreign reserve crisis or a worse macroeconomic situation (Conway 1994). However, relying on the IMF conditionality may be just a way to impose domestically unpopular austerity policies (Przeworski and Vreeland 2000).

Table 9.1 shows a summary of data on currency crises based on our definition during the period from 1970 to 1997 . There were 192 currency crisis episodes during this period. The number of crises was increasing over time, from forty in the 1970s, to sixty nine in the 1980s, to eighty three in the 1990s (1990-97). According to this data set, the number of countries that experienced at least one crisis was ninety nine. ${ }^{3}$ Thus, on average each country had

1. Lee, Hong, and Rhee (2001) describe the data in more detail. The authors are grateful to Kiseok Hong and Changyong Rhee for sharing their cross-country data set.

2. The data come from Lee and Rhee (2000), who compiled the information from the IMF Annual Report for each year.

3. The sample does not include the former Soviet Union countries that experienced currency crises and subsequently received financial assistance from the IMF in the early 1990s. 


\begin{tabular}{lccr}
\hline & & \multicolumn{2}{c}{$\begin{array}{c}\text { IMF Program } \\
\text { Participation }\end{array}$} \\
\cline { 3 - 4 } Period & Total Currency Crises & Yes & No \\
\hline $1970-97$ & 192 & 71 & 121 \\
$1970-79$ & 40 & 12 & 28 \\
$1980-89$ & 69 & 24 & 45 \\
$1990-97$ & 83 & 35 & 48 \\
\hline
\end{tabular}

Notes: A currency crisis is defined as occurring in the year when a country has a nominal depreciation of currency of at least 25 percent in any quarter of a year and the depreciation rate exceeds the previous quarter's change in the exchange rate by a margin of at least 10 percent. If the country under a currency crisis received financial assistance from the IMF during the year of or one year after the currency crisis, it is classified as a case of a currency crisis with IMF program participation. Our sample does not include the former Soviet Union countries and counts only independent crises by imposing a plus/minus two years window.

1.86 crises over the period. Out of the 192 crisis episodes, 72 of them featured participation in an IMF program.

\subsubsection{Macroeconomic Adjustment During the Currency Crisis}

On the basis of the currency crisis index, we investigate how the crisis-hit economies, on average, behave during the five years prior to and following the crisis. We first look at the movement of growth rates of real GDP and then investigate the sources of output changes by looking at the movements of GDP expenditure components and major macroeconomic policy variables in the typical crisis-hit country during the period before and after the crisis. We also construct a control group of tranquil observations. If a country was not subject to any crisis within a window of plus/minus two years surrounding a specific year, it is counted as a noncrisis country in that specific year.

The behavior of the macroeconomic variables between the two subgroups - one with conditional financial assistance from the IMF and the other without - is also compared.

We use the data for the period from 1970 to 1995 . Thus, we attempt to draw the stylized pattern of macroeconomic adjustment from the crisis episodes that had occurred prior to the Asian crisis. There are 176 independent currency crises during this period, and in 64 episodes of them the countries participated in an IMF program.

\section{Real Gross Domestic Product Growth}

Figure 9.1 shows the movements of the average GDP growth rates during the five years prior to and following the crisis; that is, from $t-5$ to $t+5$, 


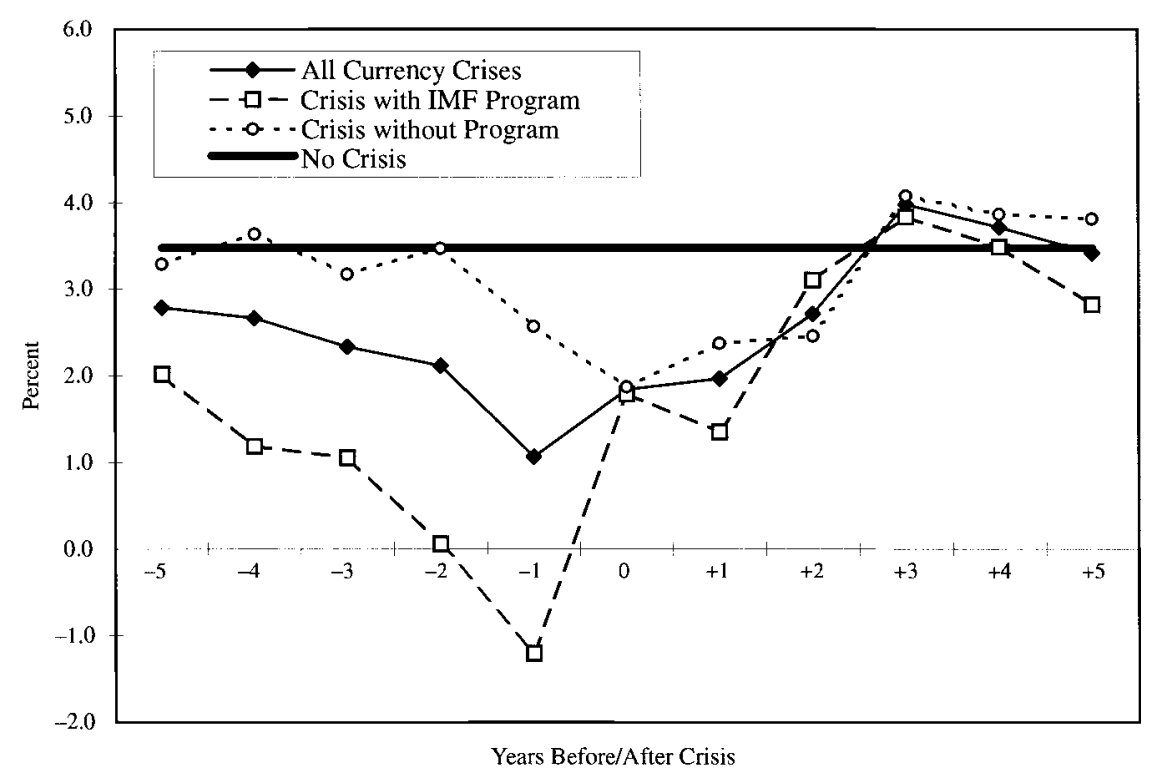

Fig. 9.1 Changes in GDP growth rates during the currency crises

where $t$ is the year of a currency crisis. For comparison, we include a straight line, which indicates the average GDP growth rate during the tranquil period, which did not experience a currency crisis or enter into an IMF program within a window of plus or minus two years.

In general, we find that the growth rates, on average, exhibit a V-type pattern of adjustment over the period before and following the crisis. The growth rates during the period three to five years prior to the crisis are slightly lower than the average during the tranquil period of 3.5 percent. The growth rate continues to decline over time, from 2.7 percent in $t-4$ to 1.1 percent in $t-1$, implying that economic conditions are aggravated prior to the eruption of a crisis.

The growth rate increases slightly in the crisis year, which confirms that most currency crises have indeed been expansionary. As in Gupta, Mishra, and Sahay (2000), we also find that about 70 percent of the currency crises in our sample led to an output increase in the crisis year. The average GDP growth rate of the crisis-hit countries remains at about 1.9 percent over the crisis year and one year after. However, the GDP growth rate recovers its noncrisis level quickly, in three years after the crisis, reaching 4.0 percent in $t+3$ - that is, about 0.5 percentage points higher than the average of the noncrisis economies. Thus, the growth rate tends to exceed its precrisis or tranquil period average, indicating that after a crisis the country's level of GDP returns to the level of its precrisis growth path. Eventually, the growth rate tapers off and returns to the level of the tranquil period in four and five 
years after the crisis. This V-type pattern and the speed of recovery are broadly consistent with the findings in Hong and Tornell (1999) and Gupta, Mishra, and Sahay (2000).

Figure 9.1 compares the behavior of the GDP growth rates between the two subgroups, one with conditional financial assistance from the IMF and the other without. We find that the adjustment process shows a much sharper V-type pattern in the program countries than in the nonprogram countries. The program countries start with lower growth rates of around 1.2 percent in $t-4$ and continue to slow down. They reach the trough, where the growth rate is -1.2 percent, in one year prior to the initiation of the currency crisis.

This magnitude of decline in growth rates is much larger than that of the nonprogram countries. At the trough, the growth rate of the crisis-hit program countries is about 4.7 percentage points lower than that of the noncrisis economies. Thereafter, rebounding from the deeper trough, the program countries show a quicker recovery. The GDP growth rate begins to recover from the crisis year and reaches its precrisis level quickly, within two years after the onset of a crisis. The nonprogram countries also begin to recover a year after the crisis, and then their growth rates stabilize at the noncrisis level from $t+3$.

The fact that the program countries have much lower growth rates than the nonprogram countries confirms that only a very serious macroeconomic situation forces a country to enter into agreements with the IMF. Nevertheless, it is intriguing that the crisis-hit countries show a quicker recovery from a deeper recession with participation in the IMF program.

\section{Gross Domestic Product Expenditure Components}

Panels A to F of figure 9.2 show the movements of the components of GDP expenditure during the five years prior to and following the crisis.

Panel A shows that the share of private-consumption expenditure in GDP remains stable over the period. In other words, consumption moves closely with GDP. The adjustment pattern is similar in both program and nonprogram countries. For the overall period, the ratio of consumption to GDP in the crisis-hit economies exceeds the noncrisis tranquil period average, indicating that private consumption is high in the crisis-hit countries, and even after a crisis these countries' level of private saving does not increase to the level of the noncrisis countries.

Panel B of figure 9.2 shows that, in contrast to consumption, the investment (private plus public investment) ratio shows more fluctuations. The level is no higher in the crisis-hit economies than in the noncrisis countries. For four to five years prior to the crisis, the investment ratio remains at an average level of tranquil observations of 22.8 percent. Thus, a stylized fact is that the crisis-hit countries have had "overconsumption," but not necessarily "overinvestment," compared to the level of the noncrisis countries. In 


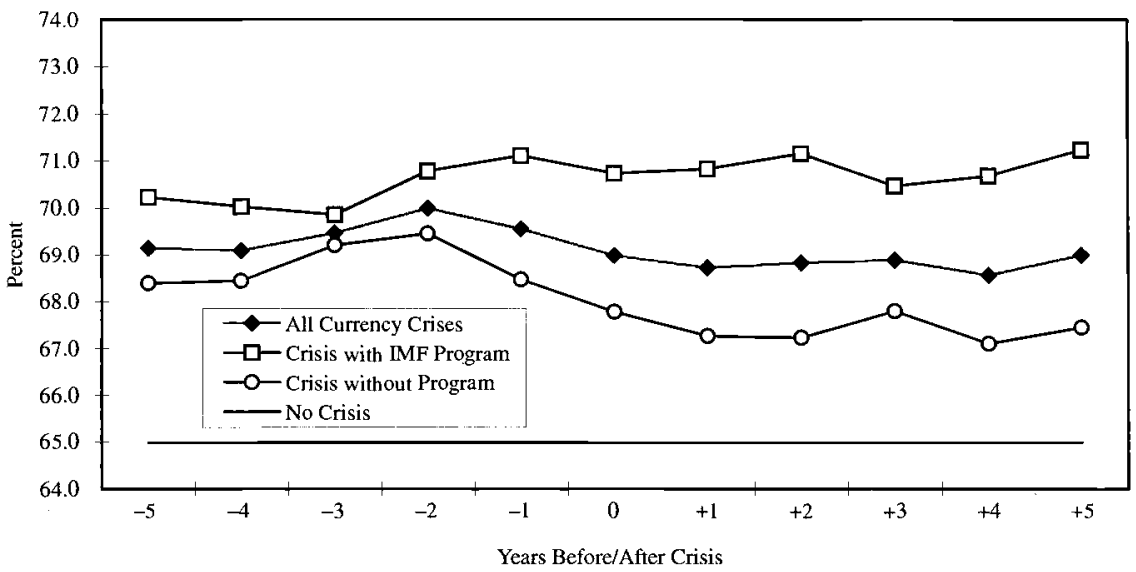

B

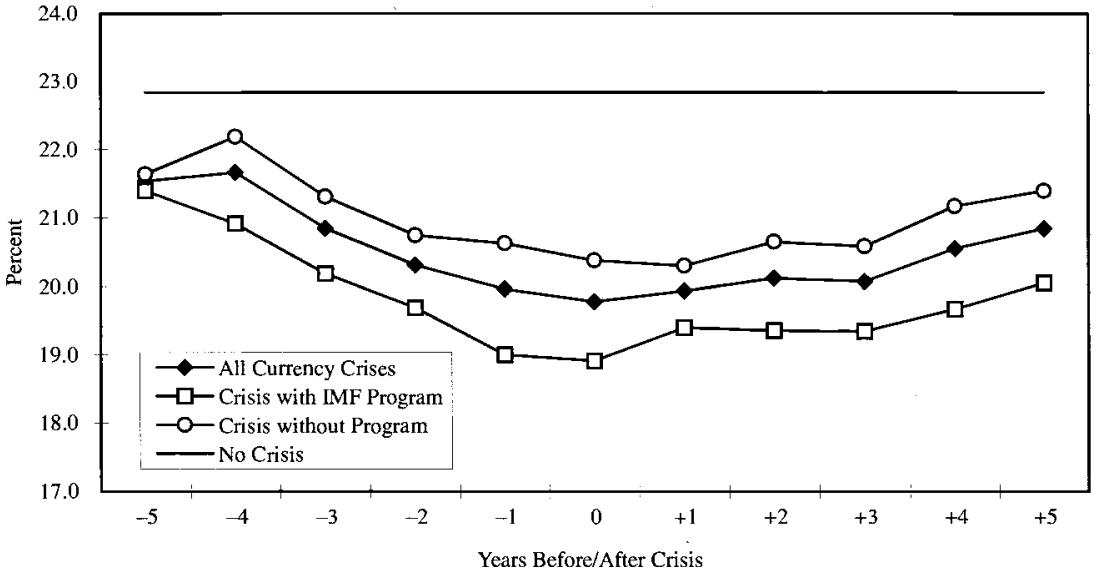

C

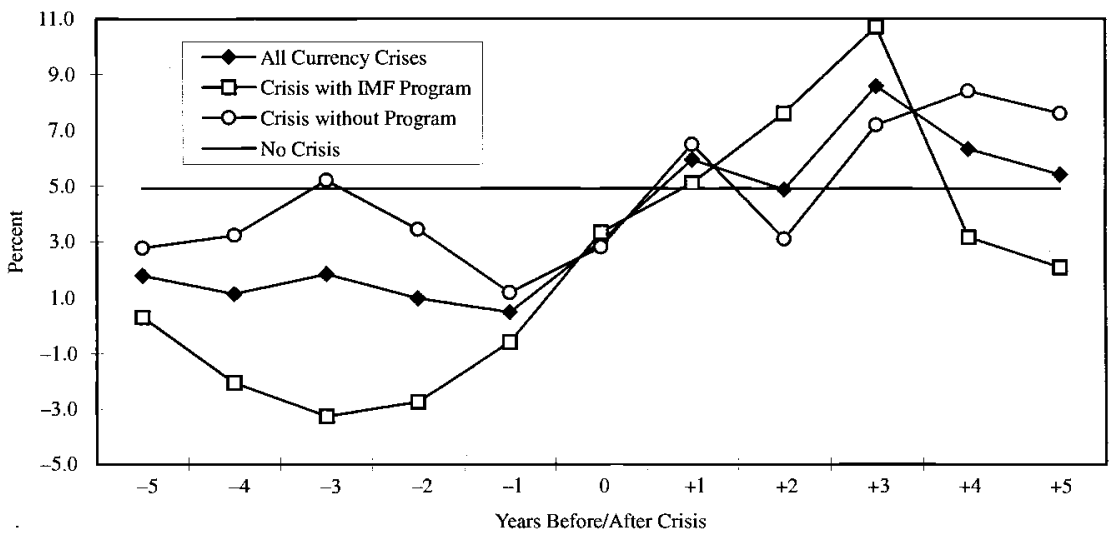

Fig. 9.2 Changes in GDP expenditure components during the currency crises: $A$, private consumption in GDP; $B$, investment rate; $C$, real export growth rate; $D$, export share in GDP; $E$, real import growth rate; $F$, import share in GDP. 


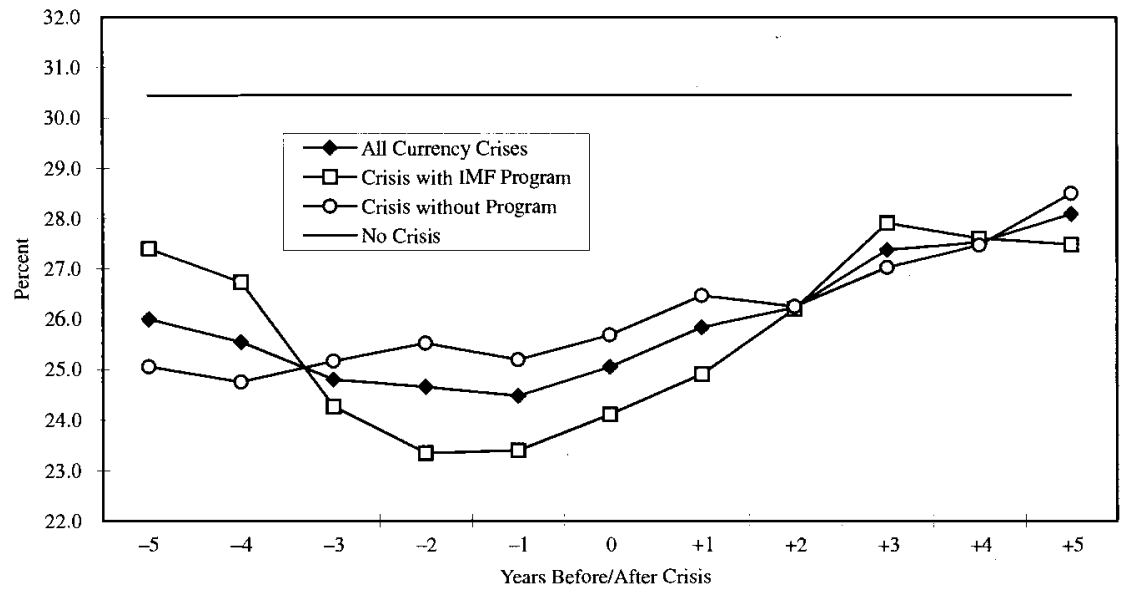

E

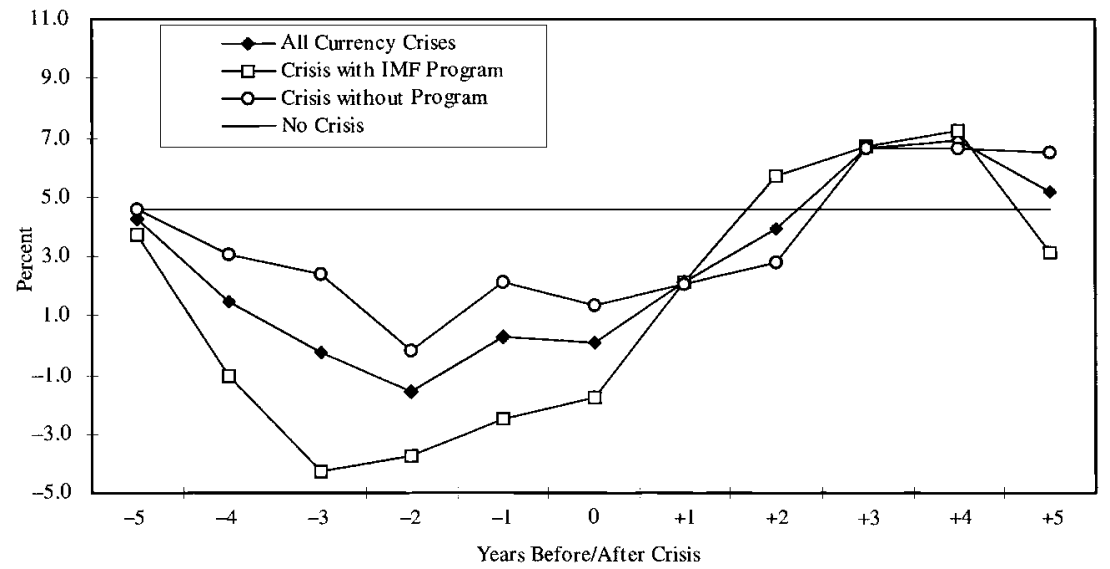

F

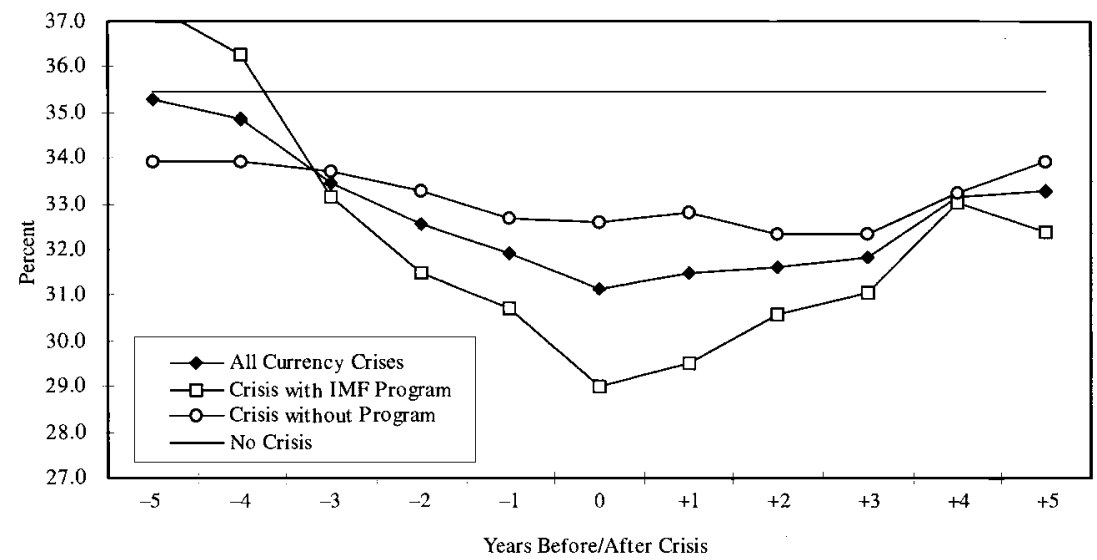

Fig. 9.2 (cont.) 
the crisis-hit countries, the investment rate tends to decline during the precrisis period, reaching 19.8 percent in the crisis year. After the crisis, the investment rate increases gradually but does not return to the level of the precrisis or tranquil period, remaining at 20.9 percent for five years following the crisis. A popular claim regarding the role of the IMF conditionality is that the austerity program has an adverse effect on investment. Panel B of figure 9.2 seems to support this claim. The IMF-program countries have experienced a more severe investment contraction than the other group in the precrisis period, as the investment ratio declines continuously from 21.4 percent in $t-5$ to 18.9 percent in $t$. In the postcrisis period of the crisis-hit countries in which an IMF program is introduced, the investment rate does not recover to the precrisis level, remaining at 19.7 percent in $t+4$ and 20.1 percent in $t+5$. In contrast, the investment rate returns to the precrisis level in the nonprogram crisis-hit countries in five years after the crisis.

In the crisis-hit countries, domestic expenditure or demand either slowly recovers or remains permanently below the precrisis level. In contrast, export demand shows a quick recovery during the postcrisis period. Panel $\mathrm{C}$ shows that in the crisis-hit countries, real export growth rates jump from less than 1 percent in $t-1$ to 3.0 percent in the crisis year and to 5.9 percent in $t+1$, and then they remain at over 5 percent over the postcrisis period. For both program and nonprogram countries, export growth during the postcrisis period is faster than that of the precrisis or tranquil period and, thus, leads a strong recovery. Consequently, as shown in panel $\mathrm{D}$ of figure 9.2, after the currency crisis the export share increases permanently above the precrisis level. However, note that on average the export share in all crisis-hit countries is still lower than that of the noncrisis average.

During the early postcrisis period the quick recovery of export growth is accompanied by a contraction of import demand. The pattern of import reduction is more conspicuous in the program countries where import growth rates are negative in the precrisis period as well as the crisis year. Panels E and $\mathrm{F}$ of figure 9.2 show that although the growth rate of imports recovers to the precrisis and noncrisis average in two years following the crisis, its share in GDP remains below the noncrisis average of 35.5 percent. The growth of exports and imports shows that the ratio of current account to GDP improves quickly after the crisis. Thus, net exports tend to lead the recovery in the crisis-hit countries.

\section{Macroeconomic Policy Indicators}

Public consumption is an indicator of fiscal policy. Panels A and B of figure 9.3 show that public consumption growth rates tend to slow down slightly in the crisis year and then recover to the precrisis as well as noncrisis average. However, in the first year following the crisis, there is contrasting behavior between the program countries and nonprogram countries. Whereas the public consumption growth rate is over 5.0 percent for the 
A

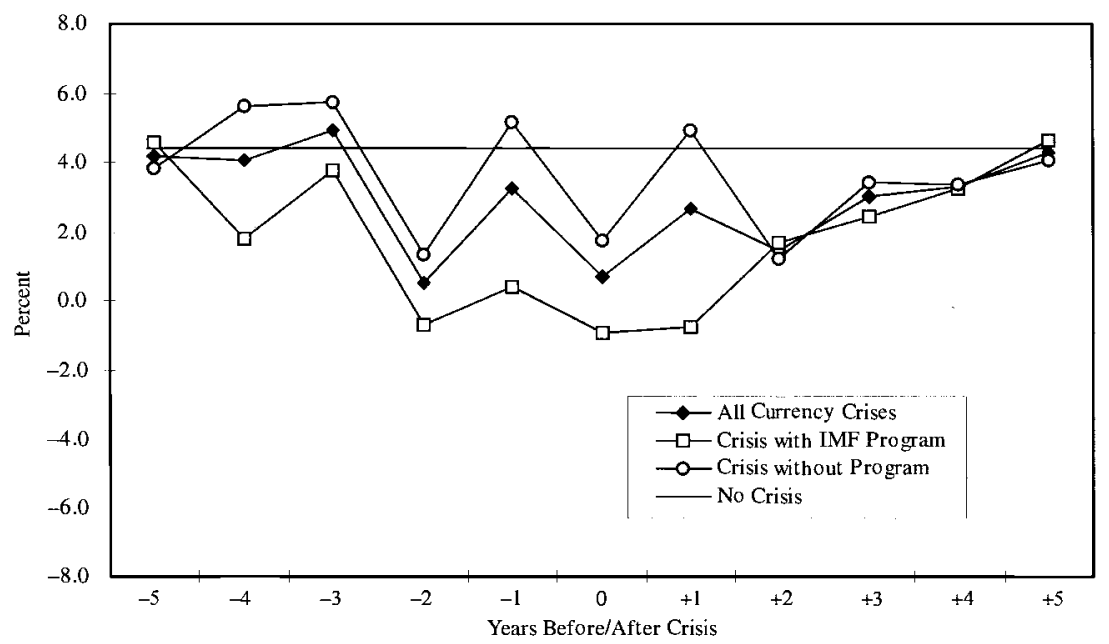

B

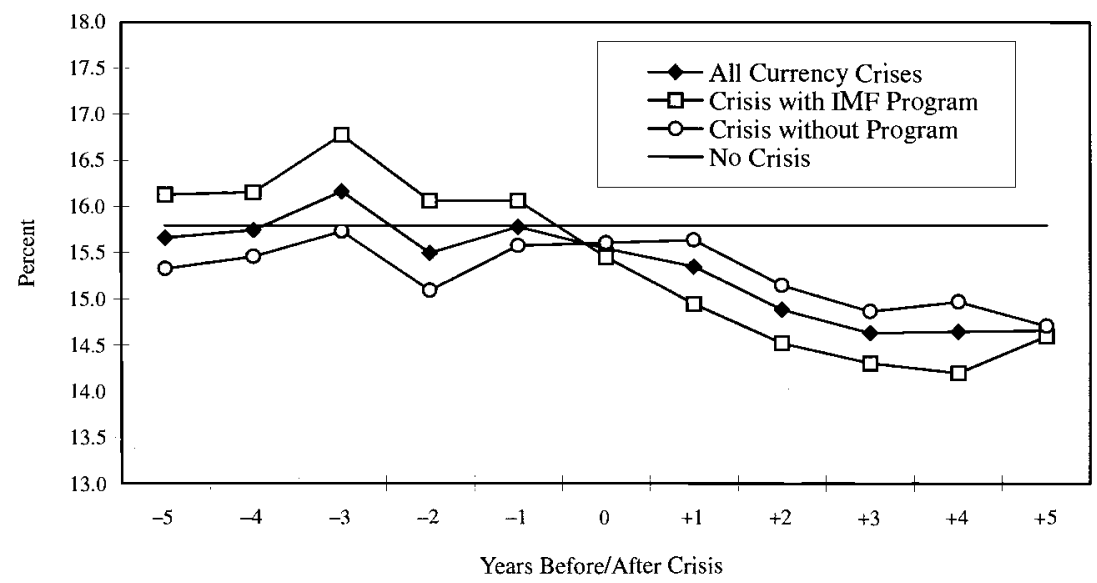

Fig. 9.3 Macroeconomic policy indicators during the currency crises: $A$, real public consumption growth rate; $B$, public consumption in GDP; $C$, real money supply (M2) growth rate; $D$, real bank credit growth rate.

nonprogram countries, it is -0.8 percent for the program countries in the year of $t+1$. This confirms that an agreement with the IMF introduces a contractionary fiscal policy in the program country. Reflecting this sharp contraction in public consumption expenditure, the ratio of public consumption to GDP declines quickly in $t+1$ with the IMF program. The ratio remains at the level lower than the precrisis or noncrisis average in both program and nonprogram countries even five years after a crisis.

Like fiscal policy, monetary policy of the program countries contrasts 
C

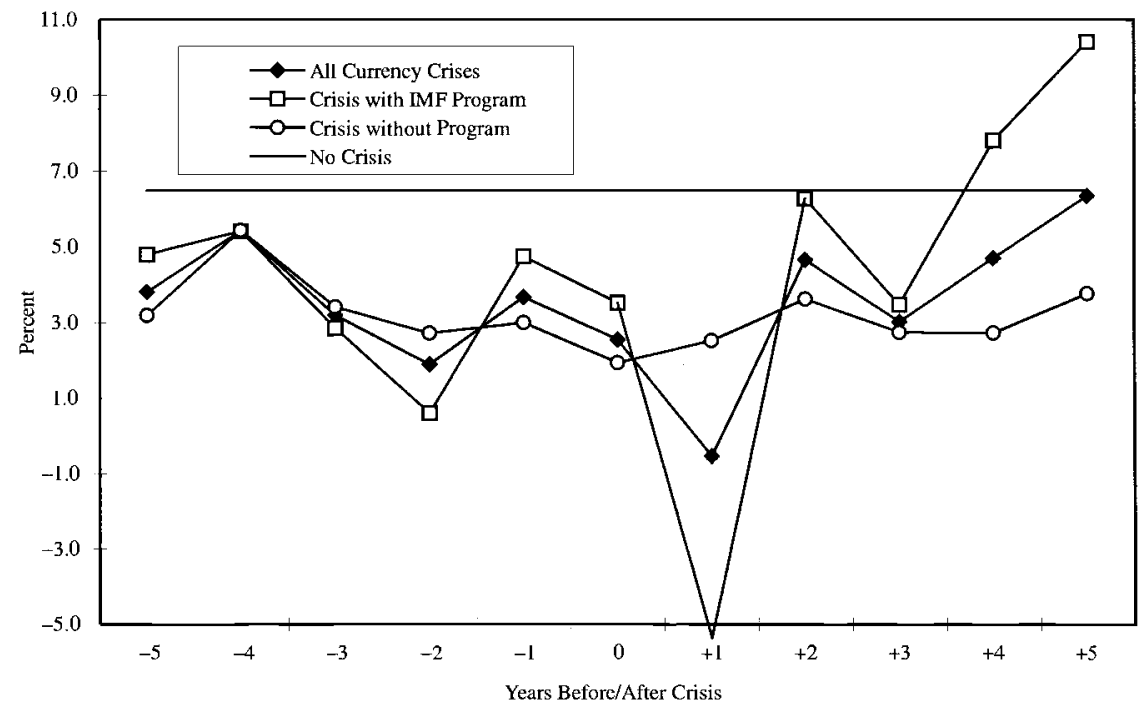

D

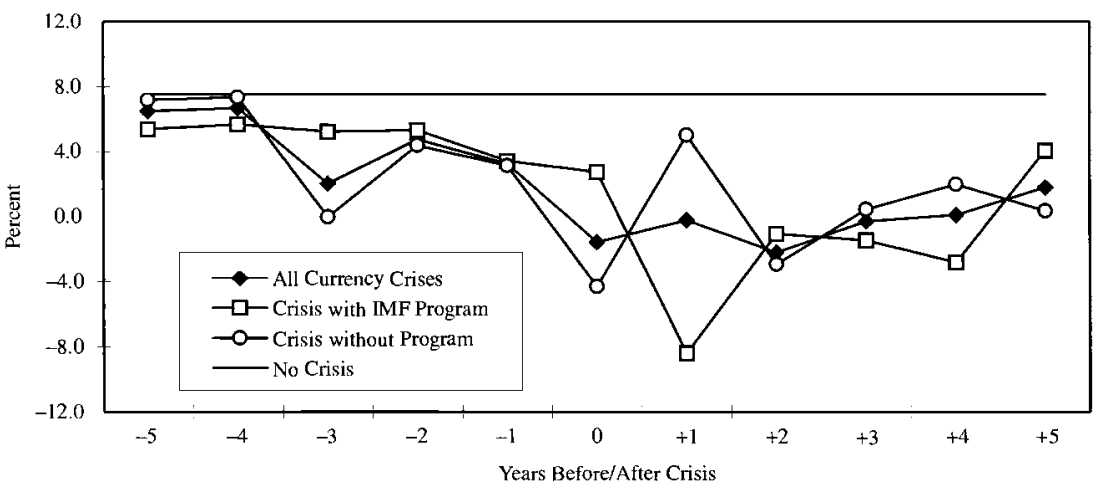

Fig. 9.3 (cont.)

sharply with that of the nonprogram countries. Panel C of figure 9.3 shows that the real money supply growth rate remains positive throughout the years following the crisis and increases over time to return to the precrisis level in five years after the crisis in the nonprogram countries. In contrast, in the sample of the crisis-hit countries with IMF program participation, money supply growth is negative. Thereafter, it returns to the precrisis average growth rate. The sharp reduction in money supply in the program countries implies that, as in fiscal policy, participation in an IMF program brings in tight monetary policy in the crisis-hit economy.

It is claimed that a currency crisis often develops into a banking crisis. As 


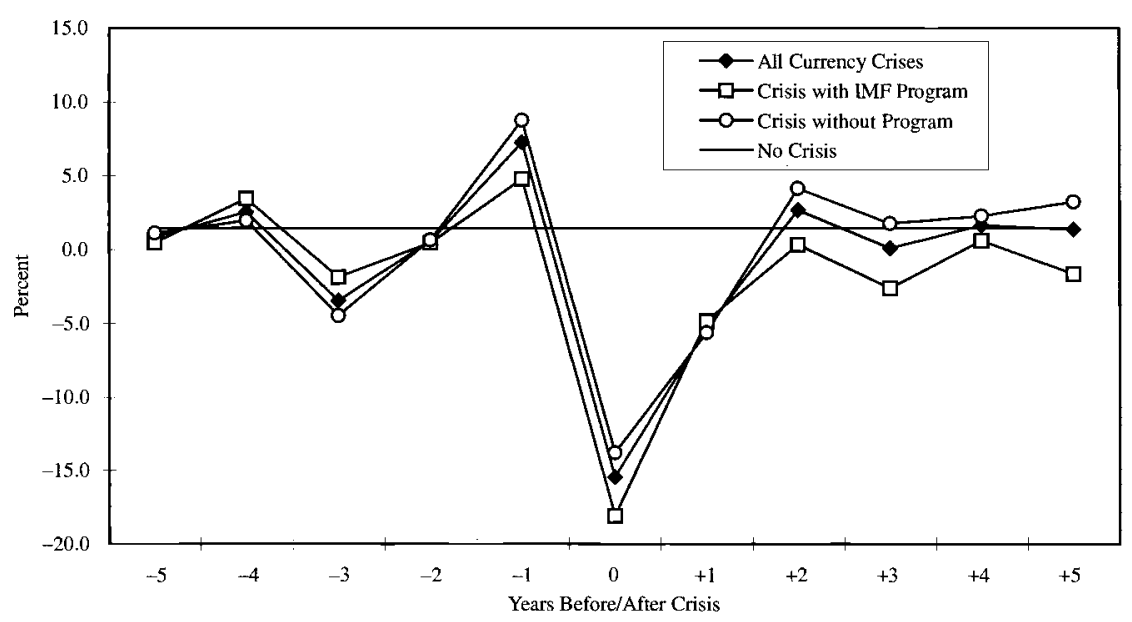

Fig. 9.4 Change in real exchange rate during the currency crises

international lending declines suddenly, a weak banking sector is unable to play a proper intermediation role. Banks reduce the supply of credit to the private sector. Panel D shows that credit supply growth indeed slows down in the crisis-hit countries. For four to five years prior to the crisis, the real credit growth rate is 7.4 percent. Thereafter, credit growth rates decline over time, reaching -1.6 percent in the crisis year. Even five years after the crisis, credit growth does not return to the level of the precrisis or tranquil period. The slowdown of real credit growth is more pronounced in the IMFprogram countries. The supply of real credit declines by more than 8 percent in the year following the crisis and thereafter continues to slow down throughout the postcrisis period.

The robust growth of net exports during the postcrisis period is likely to be related to the real exchange depreciation associated with (or caused by) the currency crisis. Figure 9.4 shows that a currency crisis causes a sharp real depreciation of the exchange rate by about 15 percent in the crisis year. The real exchange rate also depreciates by 5.3 percent in the year following the crisis. Thereafter, it appreciates about 2 percent per year. Hence, the real exchange remains depreciated after the crisis. The pattern of adjustment in the real exchange rate is similar in the program and nonprogram countries.

\subsubsection{Determinants of the Postcrisis Recovery}

We believe there are a large number of factors that determine the stylized pattern of adjustment in real output growth in the crisis-hit countries. Broadly speaking, there are four major factors that influence the adjustment pattern: (a) the origin and nature of the shock; (b) initial conditions; (c) domestic policies; and (d) external environments. 


\section{Origin and Nature of the Shock}

The origin and nature of the shock that has provoked a crisis can influence the evolution of the crisis. Many currency crises can be attributed to macroeconomic mismanagement - large budget deficits and consequent monetary expansion in a fixed exchange rate regime - as was the Latin America debt crisis in the early 1980s. In this case, real depreciation of the currency and contraction of domestic absorption help to restore internal and external balance, leading to improvement in the economy.

Investors' panic can intensify the effects of speculative attacks on currency. In particular, when the capital account is liberalized, a bad expectation by foreign investors can easily lead to a sudden reversal of foreign lending, thereby causing a significant contraction of the domestic economy. In particular, the adverse impact will be magnified if domestic corporations and financial institutions are heavily leveraged by large, unhedged, and short-term foreign currency debts. When a sharp and unexpected depreciation wreaks havoc with highly leveraged corporate and bank balance sheets, a sudden reversal of capital flows exacerbates the downturn in investment and the economy (Krugman 1999; Aghion, Bacchetta, and Banerjee 2000). However, once the investors' panic calms down and foreign capital resumes its inward flow, the economy can rebound quickly to its longterm trend.

\section{Initial Conditions}

Differences in initial conditions could result in different patterns of adjustment. For example, structural variables such as per capita output and openness could be important in determining the pattern of postcrisis recovery.

The level of initial per capita GDP can influence the growth rate in the postcrisis period. In growth theory, a country with a lower initial per capita GDP is in a more favorable position for future growth. The fundamental idea is that the gap in existing capital and technology between the current and steady-state levels offers a chance for rapid catching up, via high rates of capital accumulation as well as the diffusion of technology from more technically advanced economies. In addition, when a currency crisis leads an economy to a lower level of per capita income relative to that of its own trend, the subsequent growth rate of the economy that rebounds to its potential growth would be higher.

Openness can also influence the speed and extent of the postcrisis recovery. When the economy is more export-oriented, a quicker improvement in the current account follows a currency devaluation. Lee and Rhee (2000) argue that the quick recovery of the Korean economy may have been possible because of its openness and export orientation. An export-oriented economy benefits more from devaluation after the crisis, and a subsequent 
improvement in the current account could in turn help restore foreign investors' confidence and hence stability in the foreign exchange market.

Several studies also point out that the behavior of macroeconomic variables prior to the crisis can influence the degree of real output contraction. For example, a rapid expansion of bank credit or lending boom during the precrisis period is critical to the postcrisis recovery (Sachs, Tornell, and Velasco 1996; Hong and Tornell 1999). Gupta, Mishra, and Sahay (2000) find that the higher the size of short-term external debt and the amount of private capital flows in the years prior to the crisis, the more severe the contraction of output during the crisis period.

\section{Policy Factors}

Macroeconomic and structural reform policies implemented by the government for crisis management can play a key role in the postcrisis adjustment of real output. Fiscal policy has a direct impact on domestic demand. Monetary policy plays a critical role in determining domestic consumption and investment.

In addition to the macroeconomic stabilization policies, structural reform programs can have significant effects on the adjustment path. It is often argued that structural reforms introduced by the IMF play a catalytic role in resuming foreign trade and private capital inflows to a crisis-hit economy and thus contribute to its fast recovery, because the commitment to the reform program improves foreign investors' confidence in the economy. The critics of the IMF program, however, argue that the implementation of financial restructuring in conjunction with contractionary macroeconomic policies can make a credit crunch more severe than otherwise after the crisis.

For external demand, a larger depreciation of the exchange rate is expected to increase export earnings while cutting down import demand to improve the current account.

\section{External Environments}

A global economic environment is also critical to the postcrisis adjustment of crisis-hit countries. Business fluctuations of the world economy can influence postcrisis growth, because they have a substantial impact on the terms of trade and export earnings of the crisis-hit country.

To the extent that the relevant data are available, we carry out an empirical assessment of the factors determining the pattern of postcrisis recovery. The explanatory variables that we consider to explain the speed and the extent of postcrisis recovery include per capita real GDP in the crisis year; world economic growth, which is an average of per capita GDP growth rates of a crisis-hit country's trading partners weighted by its trade share; an interactive term of the real exchange depreciation rate with openness 
(trade-GDP ratio); real public consumption growth; and real money supply growth. We also include an investment rate. ${ }^{4}$

The regression also includes a dummy variable for the IMF-program countries to see if participation in an IMF program had any impact on the recovery process. Upon entering an agreement with the IMF, a member government subscribes to the IMF conditionality, which typically entails fiscal austerity, tight monetary policy, and currency devaluation. Because we include macroeconomic policies variables separately in the regression, the dummy variable may be able to capture the effect of the IMF program participation in postcrisis recovery.

We also control the differences in country-specific factors that may influence the potential growth path, by including the average growth rate for three to five years prior to the crisis. However, we do not include the precrisis macroeconomic policy variables in the regressions, because the impact of these variables on the postcrisis recovery is extensively discussed in Hong and Tornell (1999) and Gupta, Mishra, and Satay (2000). Also, we cannot incorporate any variables that measure structural vulnerabilities of the corporate and financial sectors due to the lack of broad cross-country data.

The dependent variable in the regression is the average growth rate of real GDP during the postcrisis period over $k$ years. ${ }^{5}$

$$
y_{i, t+k}=\frac{1}{k} \sum_{j=1}^{k}\left(\ln _{\mathrm{GDP}_{i, t+j}}-\ln \mathrm{GDP}_{i, t+j-1}\right), \quad I=1, \ldots, N,
$$

where $\mathrm{GDP}_{i, t+j}$ is real GDP for country $i$ in the $j$ years after the crisis year $(t)$ and $N$ is the number of crisis episodes in our sample. Then, $y_{i, t+k}$ represents the real GDP growth rate, averaged over the postcrisis period of $k$ years. Because we are mostly interested in short-term recovery, we choose $k$ from 1 to 5 . In the previous literature, $k$ was often chosen arbitrarily, and thus cross-section data in which each country had only one observation were used for empirical investigation. Our framework differs significantly in that we use panel data. Thus, we utilize both cross-section and time-dimension information. Our regression specification is as follows.

$$
y_{i, t+k}=\beta^{\prime} \mathbf{X}_{i, t+k}+\varepsilon_{i, t+k}, \quad i=1, \ldots, N, \quad k=1, \ldots, 5 .
$$

where $\mathbf{X}$ denotes the vector of the explanatory variables. Note that some independent variables, such as real GDP in the crisis year, precrisis average

4. Investment ratio can be considered an endogenous variable. The regression results do not change qualitatively when we have excluded investment ratio from the regressions. Note that investment includes public investment in addition to private investment. The regressions for investment rate are presented in table 9.4.

5. We have also estimated another specification by using the reversal of GDP growth rate between the crisis-hit (that is, $t-1$ and $t$ ) and the postcrisis period, instead of postcrisis GDP growth, for the dependent variable in the regressions. We find the results do not change much. 
growth rate, and an IMF program dummy, are identical across all five equations. Fiscal policy variable is included as an average over the period from the crisis year $t$ to the postcrisis year $t+k$, while monetary growth and real exchange depreciation variables are included as an average over the period from the crisis year $t$ to the postcrisis $t+k-1$.

We estimate this system of the five equations by a seemingly unrelated regression (SUR) technique that corrects for heteroskedasticity in each equation and correlation of the errors across the equations.

Table 9.2 displays our estimates of the basic regression for postcrisis recovery at various horizons that was applied to a total of 101 previous crisis episodes during the period from 1970 to 1995.

We find a strong and statistically significant negative relation between the initial real per capita GDP and the postcrisis growth rate at all horizons, implying that countries with lower per capita income tend to have larger incrisis episodes between 1970 and 1995)

\begin{tabular}{lccccc}
\hline & \multicolumn{5}{c}{ Dependent Variable: } \\
& \multicolumn{5}{c}{ Average GDP Growth Rate from $t+1$ to $t+k$} \\
\cline { 2 - 6 }$(t+k=)$ & $t+1$ & $t+2$ & $t+3$ & $t+4$ & $t+5$ \\
\hline Real GDP per capita at $t$ & $-2.037^{*}$ & $-1.240^{*}$ & $-1.028^{*}$ & $-0.817^{*}$ & $-0.816^{*}$ \\
$\quad$ PPP-adjusted, log & $(0.532)$ & $(0.380)$ & $(0.324)$ & $(0.283)$ & $(0.257)$ \\
Precrisis GDP growth average, & -0.137 & -0.030 & 0.060 & 0.057 & 0.090 \\
$\quad t-3$ to $t-5$ & $(0.135)$ & $(0.097)$ & $(0.083)$ & $(0.072)$ & $(0.066)$ \\
World per capita GDP growth & $0.445^{*}$ & 0.261 & $0.469^{*}$ & $0.580^{*}$ & $0.541^{*}$ \\
$\quad$ average, $t+1$ to $t+k$ & $(0.225)$ & $(0.175)$ & $(0.155)$ & $(0.166)$ & $(0.198)$ \\
Investment ratio average, & $0.133^{*}$ & $0.136^{*}$ & $0.123^{*}$ & $0.125^{*}$ & $0.104^{*}$ \\
$\quad t+1$ to $t+k$ & $(0.051)$ & $(0.037)$ & $(0.032)$ & $(0.028)$ & $(0.026)$ \\
Real exchange rate change $\times$ trade & 0.032 & 0.004 & $-0.034^{* *}$ & $-0.062^{*}$ & $-0.086^{*}$ \\
$\quad$ share average, $t$ to $t+k-1$ & $(0.023)$ & $(0.020)$ & $(0.019)$ & $(0.023)$ & $(0.029)$ \\
Public consumption growth & 0.035 & $0.057^{*}$ & $0.072^{*}$ & $0.078^{*}$ & $0.086^{*}$ \\
$\quad$ average, $t$ to $t+k$ & $(0.032)$ & $(0.025)$ & $(0.021)$ & $(0.019)$ & $(0.024)$ \\
Real money supply growth & 0.006 & 0.012 & 0.011 & 0.003 & -0.0001 \\
$\quad$ average, $t$ to $t+k-1$ & $(0.015)$ & $(0.011)$ & $(0.010)$ & $(0.009)$ & $(0.010)$ \\
IMF program participation & -1.042 & 0.194 & 0.179 & -0.215 & -0.040 \\
$\quad$ dummy & $(0.968)$ & $(0.699)$ & $(0.589)$ & $(0.515)$ & $(0.468)$ \\
No. of crisis episodes & 101 & 101 & 101 & 101 & 101 \\
$R^{2}$ & 0.14 & 0.17 & 0.24 & 0.30 & 0.33 \\
\hline
\end{tabular}

Notes: Standard errors reported in parentheses. The system has five equations, in which the dependent variables are the average real GDP growth rates over $k$ years from the crisis year, $t$. The system is estimated by the seemingly unrelated regression (SUR) technique, which allows for different error variances in each equation and for correlation of these errors across equations. Each equation has a different constant term, which is not reported. An increase in real exchange rate indicates a real appreciation.

**Significant at the 90 percent level.

*Significant at the 95 percent level. 
creases in GDP growth over the period after the crisis. The impact of initial GDP on the postcrisis recovery is much larger in the year following the crisis, but then it become smaller in the later years of the postcrisis period. The estimated coefficients imply that a 10 percentage point drop in per capita GDP in the crisis year is associated with a 0.2 percentage point [2.04 * $\ln (0.9)$ ] increase in GDP growth in the first year after a crisis erupted, but with a 0.1 percentage point increase on average over five years after the crisis.

The world growth variable also has a significantly positive coefficient in most of the regressions. The estimated coefficient implies that a 1 percentage point increase in world per capita GDP growth is associated with about a 0.5 percentage point increase in GDP growth of the crisis-hit country in the postcrisis period.

The result also confirms the strong association between investment and GDP growth over the period of adjustment in the crisis-hit economies. The coefficients show that an increase of 10 percentage points in the ratio of investment to GDP is typically associated with an increase in the growth rate of about 1.3 percentage points per year.

Among the macroeconomic policy variables, the fiscal variable (measured by public consumption growth) turns out to be most significant for the recovery in all postcrisis periods except for the year of $t+1$. The estimated coefficients imply that an increase of the public consumption growth rate by 10 percentage points leads to an increase in GDP growth rate by $0.5-0.9$ percent.

In contrast to the positive and significant contribution of fiscal policy, monetary policy turns out to be less important for postcrisis recovery. The average growth rates of real money supply are insignificant in all equations. One might argue that the weak effect of monetary policy on real output even in the short run is not credible. However, in our view, the real impact of monetary policy is ambiguous in the crisis-hit economies. Contractionary monetary policy, which is part of the IMF programs, can contribute to postcrisis growth as it helps stabilize prices and improve the current account. ${ }^{6}$

The test shows that the interactive term between trade share and exchange rate depreciation variables has a significant impact on the postcrisis GDP growth in only a few years following a crisis. The estimated coefficient shows that for the country with the average openness ratio of 0.6 , a real exchange depreciation of 10 percent raises real GDP growth rate by about 0.4 percent per year over the four years after the crisis.

We also examined whether the agreements with the IMF had any impact on the postcrisis recovery. The estimated coefficient turns out to be statistically insignificant. Hence, there is no evidence that IMF programs had any

6. Goldfajn and Gupta (1999) find that the use of tight monetary policy is accompanied by a sharper recovery of output during the currency crises. 


\begin{tabular}{lccc}
\hline & \multicolumn{3}{c}{$\begin{array}{c}\text { Dependent Variable: Average Investment Ratio } \\
\text { from } t+1 \text { to } t+k\end{array}$} \\
\cline { 2 - 4 }$(t+k=)$ & $t+1$ & $t+2$ & $t+3$ \\
\hline GDP growth in the precrisis & $0.281^{* *}$ & $0.410^{*}$ & $0.349^{*}$ \\
period average, $t-3$ to $t-5$ & $(0.152)$ & $(0.141)$ & $(0.156)$ \\
Real exchange rate change & 0.007 & -0.012 & 0.011 \\
$\quad$ average, $t$ to $t+k-1$ & $(0.040)$ & $(0.036)$ & $(0.040)$ \\
Public investment-GDP ratio & $1.460^{*}$ & $1.319^{*}$ & $1.256^{*}$ \\
average, $t$ to $t+k$ & $(0.231)$ & $(0.131)$ & $(0.111)$ \\
Real money supply growth & 0.010 & $0.085^{*}$ & $0.133^{*}$ \\
average, $t$ to $t+k-1$ & $(0.036)$ & $(0.040)$ & $(0.046)$ \\
IMF program participation & 1.002 & 1.748 & 1.798 \\
dummy & $(1.296)$ & $(1.222)$ & $(1.158)$ \\
No. of crisis episodes & 81 & 81 & 81 \\
$R^{2}$ & 0.60 & 0.65 & 0.68 \\
\hline
\end{tabular}

Notes: Each equation is estimated by the least squares method. Robust standard errors reported in parentheses. Constant term is included, but not reported.

** Significant at the 90 percent level.

*Significant at the 95 percent level.

significant impact on the recovery process after a currency crisis when other factors were controlled. ${ }^{7}$

Macroeconomic policies may have an additional impact on growth by influencing the level of investment. Table 9.3 shows the results of regressions for the investment rate. We find that both public investment and real money supply growth play a quite significant role in promoting investment from the beginning of the postcrisis period, whereas exchange rate depreciation is insignificant. The estimated coefficient for public investment suggests that an increase of 1 percentage point in the ratio of public investment to GDP contributes to an increase in the total investment ratio by more than 1 percentage point, between 1.3 and 1.5. Hence, public investment increases total investment more than one for one, implying that public investment does not crowd out an equal amount of private investment from domestic sources by competing in product markets or financial markets. Thus, public investment, perhaps by improving the condition of social infrastructure, stimulates private investment and thus contributes to the postcrisis recovery by augmenting capital accumulation. An increase in real money supply growth by about 10 percentage points leads to an increase in investment-

7. A problem can occur in this regression when participation in the IMF program is endogenously determined. To avoid this simultaneous problem, we need to use an instrumental-variable technique. We do not implement this approach yet due to the lack of an ideal instrument. 
GDP ratio by about $0.9-1.3$ percentage points per year over the two years following the crisis.

\subsection{Assessments of the Recovery Process in East Asia}

\subsubsection{Macroeconomic Adjustments in East Asia}

The economic turmoil that broke out in Thailand in July 1997 swept through East Asia, and its devastating impacts were much more severe than anyone had expected. The countries that fell victim to the crisis suffered a sharp reduction in real income. In 1998, the growth rate plunged from the precrisis average of 7.0 percent to -13.2 percent in Indonesia, -10.4 percent in Thailand, -7.5 percent in Malaysia, -6.7 percent in Korea, and -0.6 percent in the Philippines. However, since 1999 the five crisis-hit Asian countries have managed impressive recoveries, which have been faster than the similar previous episodes of recovery in other parts of the world. The rebounding of the growth rate in 1999 was no less drastic than its free-fall. Korea stood out as the best performer in that year by growing at 10.7 percent. For the other countries, the growth rate ranged from 5.4 percent in Malaysia to 0.2 percent in Indonesia.

With the passage of time, the recovery process has gained momentum. The growth outturn in 2000 is estimated to be higher than that of 1999 in four of the affected economies - Indonesia, Thailand, Malaysia, and the Philippines. In Korea, the growth rate slowed down from 10.7 percent to 8.3 percent.

Figure 9.5 shows the GDP growth rates of the five affected economies. The adjustment process in East Asia that can be inferred from changes in

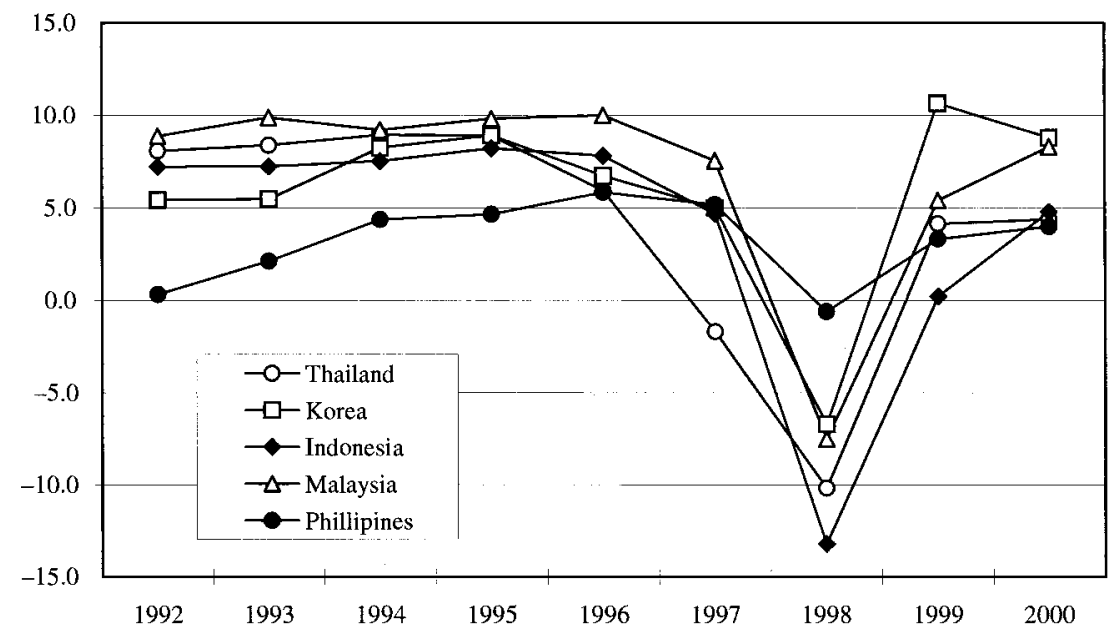

Fig. 9.5 Adjustment of real GDP growth rate in East Asia 


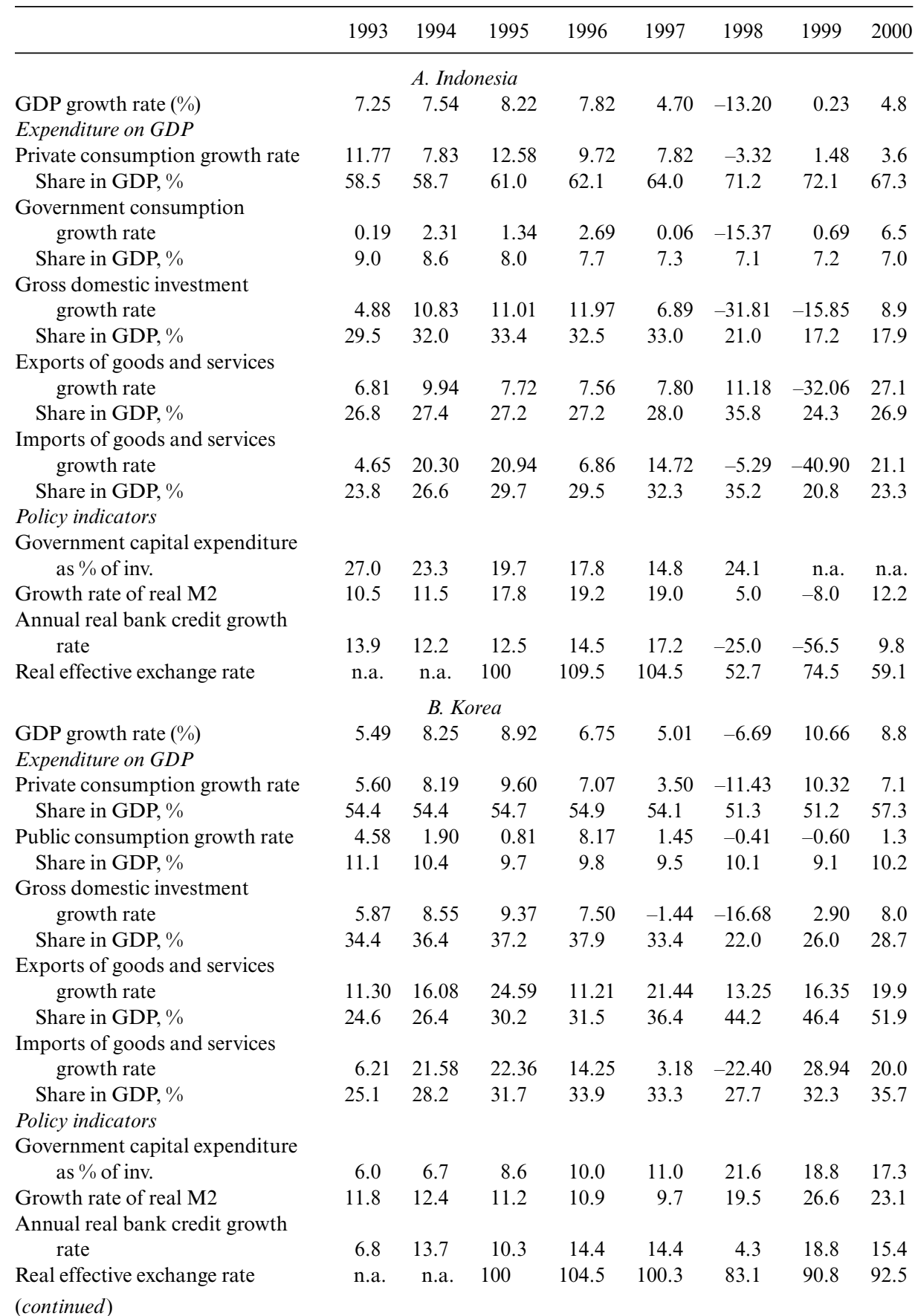




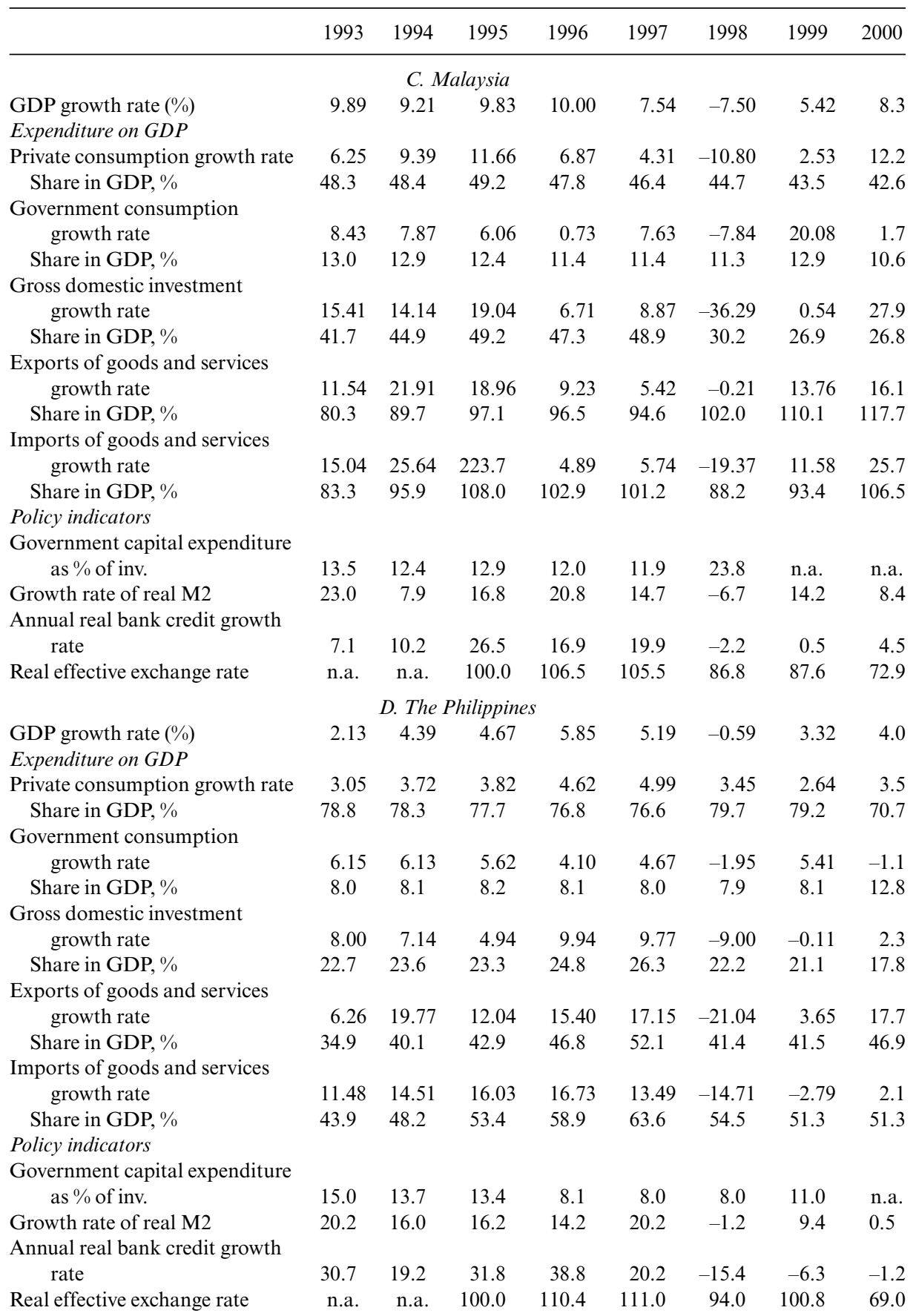


(continued)

\begin{tabular}{|c|c|c|c|c|c|c|c|c|}
\hline & 1993 & 1994 & 1995 & 1996 & 1997 & 1998 & 1999 & 2000 \\
\hline \multicolumn{9}{|c|}{ E. Thailand } \\
\hline GDP growth rate $(\%)$ & 8.38 & 8.95 & 8.90 & 5.93 & -1.68 & -10.17 & 4.16 & 4.4 \\
\hline \multicolumn{9}{|l|}{ Expenditure on $G D P$} \\
\hline Private consumption growth rate & 8.43 & 7.87 & 7.55 & 6.83 & -1.05 & -12.33 & 3.49 & 4.6 \\
\hline Share in GDP, $\%$ & 55.8 & 55.2 & 54.6 & 55.0 & 55.4 & 54.0 & 53.7 & 56.4 \\
\hline \multicolumn{9}{|l|}{ Government consumption } \\
\hline growth rate & 5.11 & 8.19 & 5.37 & 11.91 & -3.03 & 1.94 & 2.82 & 6.5 \\
\hline Share in GDP, $\%$ & 8.3 & 8.2 & 7.9 & 8.4 & 8.3 & 9.4 & 9.3 & 11.5 \\
\hline \multicolumn{9}{|l|}{ Gross domestic investment } \\
\hline growth rate & 8.55 & 10.83 & 10.04 & 8.08 & -18.59 & -35.17 & -1.72 & 11.8 \\
\hline Share in GDP, $\%$ & 40.9 & 41.6 & 42.7 & 43.0 & 33.7 & 19.0 & 20.5 & 22.7 \\
\hline \multicolumn{9}{|l|}{ Exports of goods and services } \\
\hline growth rate & 12.74 & 14.25 & 15.50 & -5.53 & 8.41 & 6.72 & 8.86 & 19.5 \\
\hline Share in GDP, $\%$ & 42.4 & 44.4 & 47.1 & 42.0 & 46.3 & 55.1 & 57.5 & 64.2 \\
\hline \multicolumn{9}{|l|}{ Imports of goods and services } \\
\hline growth rate & 11.78 & 15.75 & 19.87 & -0.52 & -11.38 & -22.28 & 20.24 & 24.6 \\
\hline Share in GDP, $\%$ & 44.9 & 47.7 & 52.5 & 49.3 & 44.4 & 38.4 & 44.4 & 47.5 \\
\hline \multicolumn{9}{|l|}{ Policy indicators } \\
\hline \multicolumn{9}{|l|}{ Government capital expenditure } \\
\hline as $\%$ of inv. & 12.9 & 13.4 & 12.0 & 16.6 & 23.4 & 29.3 & 23.1 & 17.7 \\
\hline Growth rate of real M2 & 15.1 & 7.7 & 11.3 & 6.8 & 10.9 & 1.6 & 5.1 & -0.9 \\
\hline \multicolumn{9}{|l|}{ Annual real bank credit growth } \\
\hline rate & 18.6 & 24.6 & 15.1 & 9.4 & 13.6 & -11.3 & -6.0 & -17.3 \\
\hline Real effective exchange rate & n.a. & n.a. & 100.0 & 109.2 & 102.4 & 90.0 & 93.5 & 73.6 \\
\hline
\end{tabular}

Source: Asian Development Bank online country data, available at [http://www.adb.org/Statistics/ country.asp].

Notes: The share of expenditure components in GDP is constructed based on data in constant prices. n.a. = not available.

the growth rates seems to be in general consistent with the stylized Vpattern we observe from the previous crisis episodes. However, the East Asian experience is in marked contrast to the stylized pattern of adjustment in GDP growth in that the degree of initial contraction and subsequent recovery has been far greater than what can be predicted from the previous cross-country evidence.

The initial GDP contraction in 1998 was largely caused by the collapse of investment: the level of domestic capital formation plummeted in all five countries in 1998. The contraction amounted to more than 30 percent in Indonesia, Malaysia, and Thailand, 17 percent in Korea, and 9 percent in the Philippines (table 9.4).

Compared to investment demand, private consumption fell to a lesser degree. The consumption-GDP ratio remained mostly stable in the crisis period, which is consistent with the cross-country stylized pattern. In contrast, the investment-GDP ratio dropped sharply. In Korea, for example, it fell from 33.4 percent in 1997 to 22.0 percent in 1998. Investment demand 


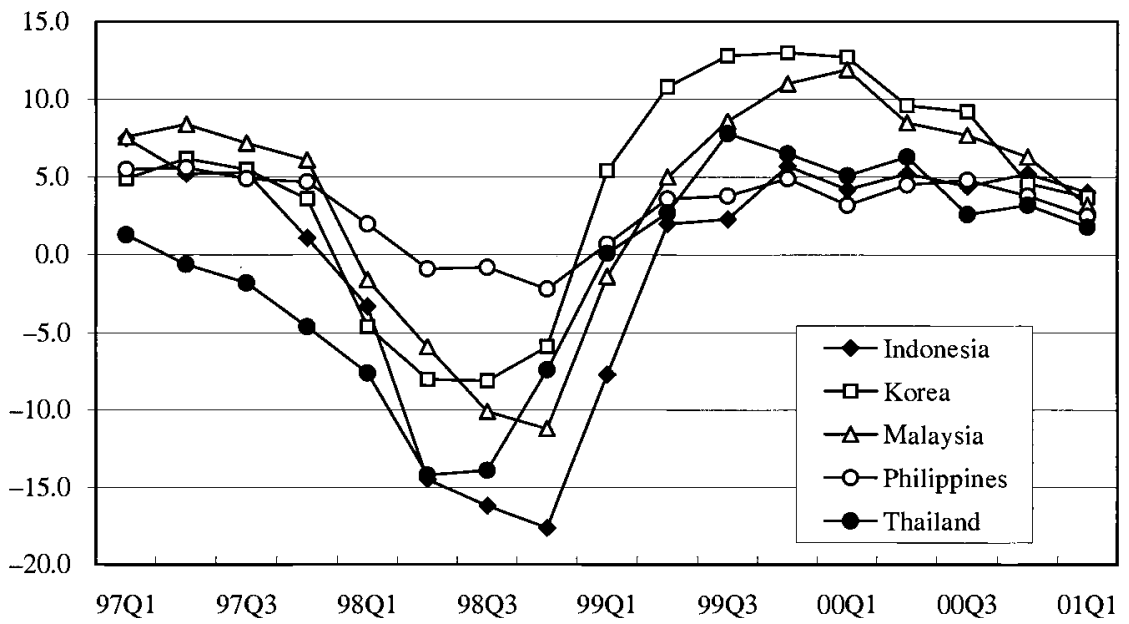

Fig. 9.6 Quarterly changes of real GDP growth in East Asia (y-o-y, \%)

A

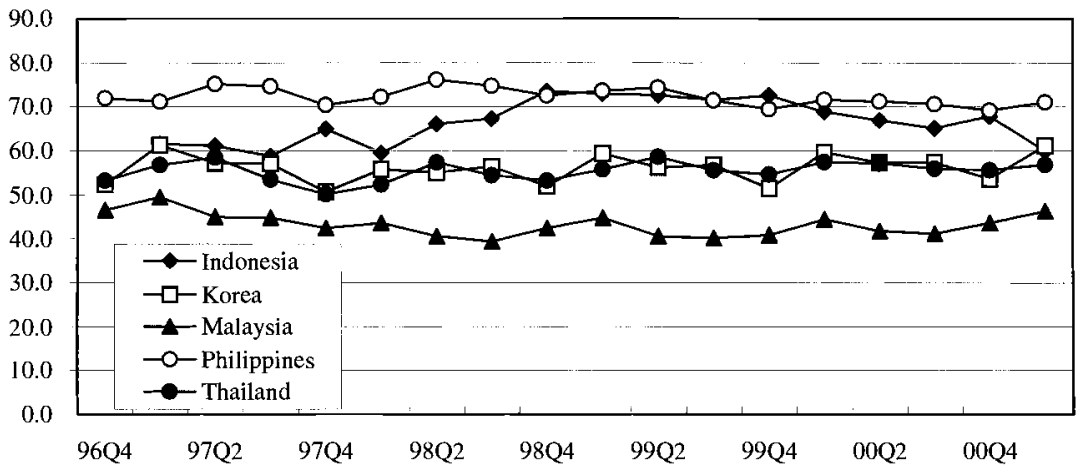

B

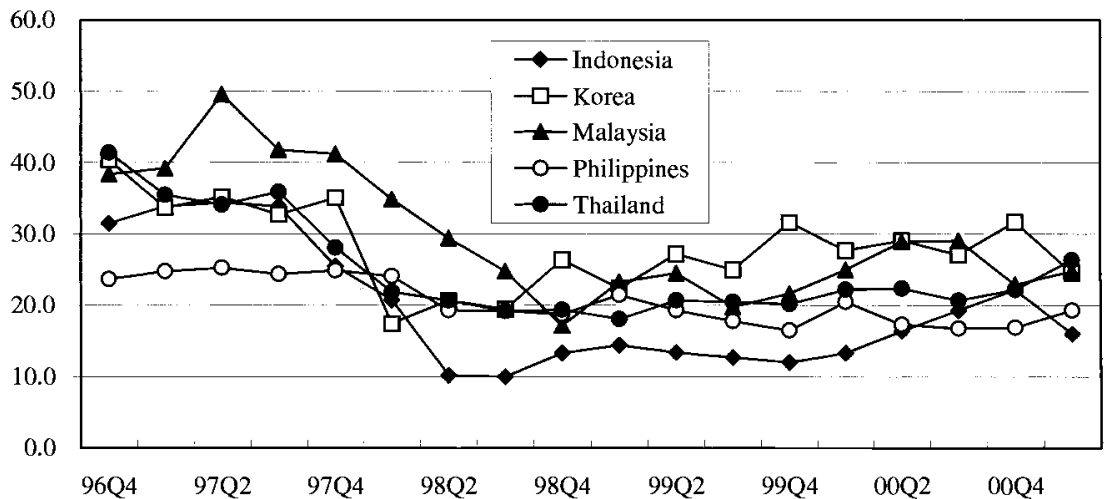

Fig. 9.7 Quarterly movements of GDP components in East Asia: $A$, private consumption in GDP; $B$, investment rate; $C$, real export growth rate; $D$, real import growth rate 


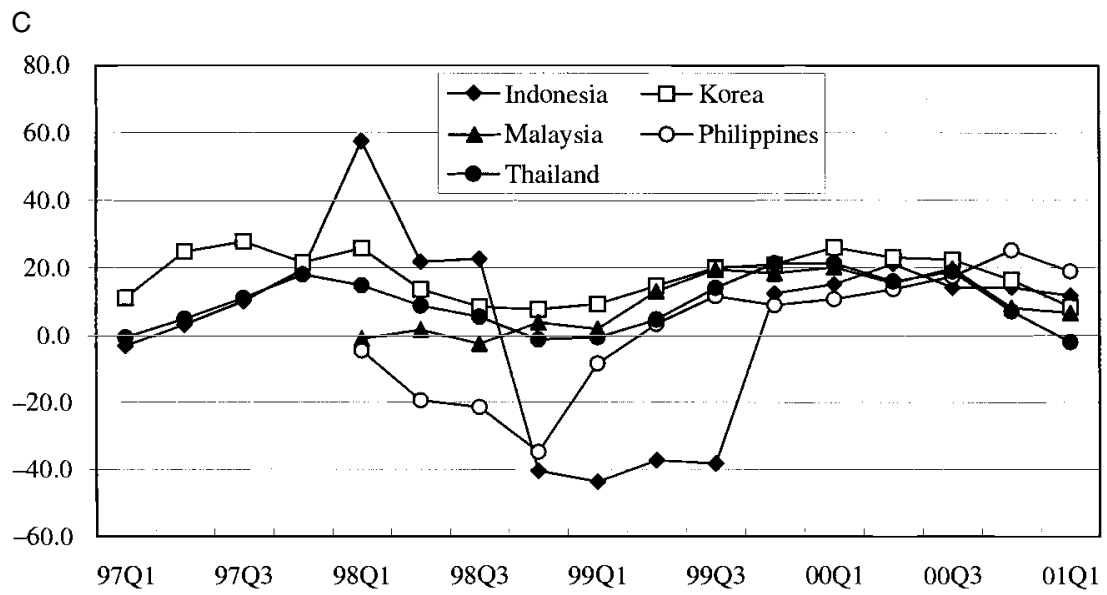

$\mathrm{D}$

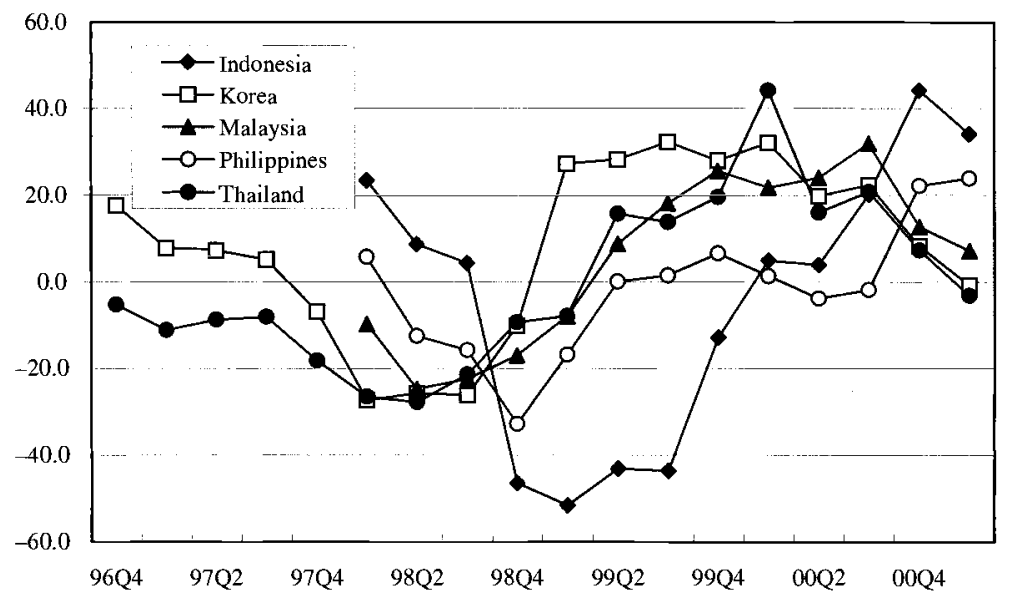

Fig. 9.7 (cont.)

started to recover somewhat in 1999 in Korea and Malaysia, but it has continued to decline in the other countries.

While domestic demand was sluggish, a large increase in net export paved way for the initial recovery of the Asian economies. Import demand declined in all of the crisis-hit countries in 1998 by a substantial amount, ranging from 22 percent in Korea and Thailand to 5.3 percent in Indonesia, whereas exports continued to grow or remained unchanged in all countries except the Philippines.

It is therefore clear that net exports led the recovery in East Asia. Figures 9.6 and 9.7, based on quarterly data, demonstrate the pattern of adjustment in more detail. A close examination of the quarterly rates of GDP growth 


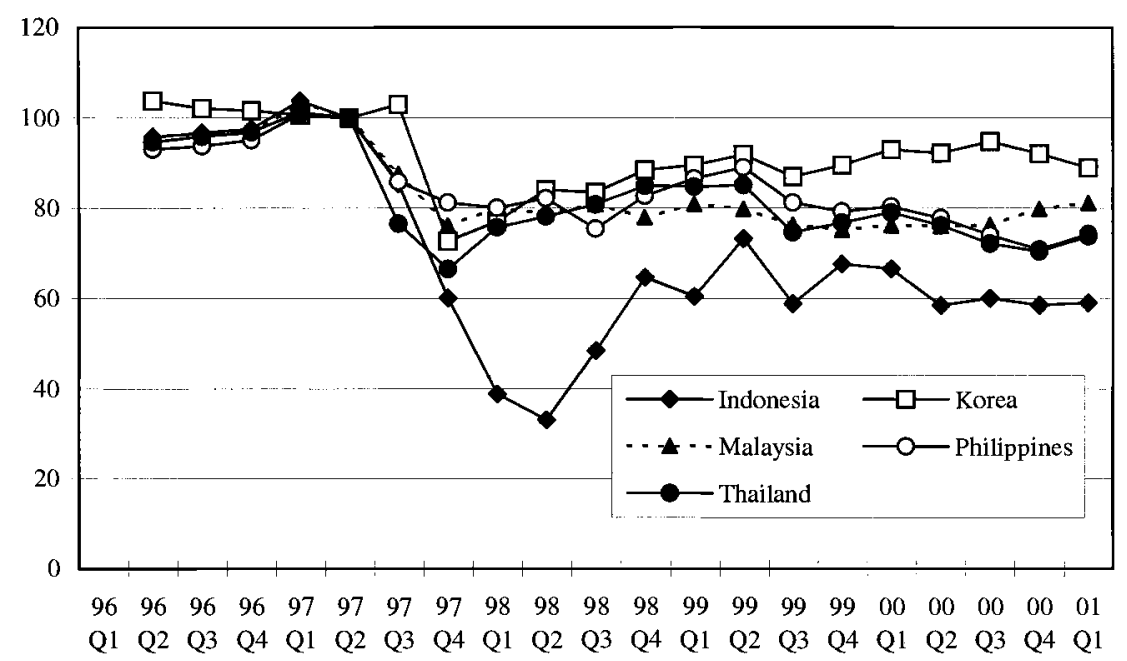

Fig. 9.8 Real effective exchange rate in East Asia (1997:2 = 100)

shows that both Korea and Thailand reached the trough as early as in the second quarter of 1998, and Indonesia, Malaysia, and the Philippines two quarters later (see figure 9.6). Overall, the recession in East Asia bottomed out in the second half of 1998, less than a year after the crisis had broken out. As shown in figure 9.7, the subsequent recovery in 1999 was led mostly by a surge in net exports. Over the postcrisis period, the ratio of private consumption to GDP has remained stable in all countries except for Indonesia. In Indonesia, private consumption expenditure rose in 1998. In Korea and Malaysia, the investment rate started to increase from the latter half of 1998, whereas in the other countries the investment ratio has declined.

An increase in public investment appears to have contributed to the resurgence of total investment expenditure in Korea and Malaysia. Table 9.4 shows that in both countries the fraction of government capital expenditure in total investment jumped from 11 percent in 1997 to over 21 percent in 1998.

The large depreciation of currency has backed up the quick surge of net exports since 1998. Table 9.4 and figure 9.8 show that the level of real effective exchange rates in the five crisis-hit East Asian countries depreciated by 22 percent on average, ranging from 12 percent in Thailand to 50 percent in Indonesia in 1998.

\subsubsection{Factors Behind the Speedy Adjustment in East Asia}

A large number of internal and external factors are likely to have contributed to the pattern of macroeconomic adjustment to the crisis in East Asia. On the basis of the cross-country evidence and available information 
on the pattern of macroeconomic adjustment in East Asia, we attempt to identify some of the factors that have engineered the postcrisis recovery.

\section{Macroeconomic Factors}

According to the empirical examination of the stylized pattern of adjustments from the previous 160 currency crisis episodes over the period from 1970 to 1995, which show a V-type adjustment of real GDP growth, a large real depreciation, expansionary monetary and fiscal policy, and an improvement in the global economic environment have been responsible for the upturn of the crisis-hit countries. In this sense, the East Asian process of adjustment is not much different from the stylized pattern. The same factors contributed to the quick postcrisis recovery of the East Asian economies.

Exchange Rate Depreciation and Openness. An important structural factor driving the speedy adjustment in East Asia may have been the region's higher level of openness. With a relatively large trade sector and export orientation, these economies benefited from a large depreciation of the real exchange rate. The level of openness in terms of the share of export and import in GDP ranges from 200 percent in Malaysia to 60 percent in Indonesia. Thus, compared to other crisis-hit economies before them, the depreciation is likely to have had a bigger impact on the more open East Asian economies. Note that the size of real exchange depreciation in the East Asian countries was comparable to the average depreciation rate in the previous crisis episodes.

One special feature of the East Asia crisis is that, compared to the crosscountry evidence, the impact of depreciation on real depreciation on real output showed up as early as one year after the crisis. The large real exchange depreciation therefore restored external balance without much delay in East Asia. The flexibility in the labor market may have facilitated this swift adjustment, because the shift of resources from the nontradables to the tradables sector elicited by the massive real exchange rate depreciation requires flexible factor market.

Favorable External Environment. The quick improvement in East Asian exports has been supported by favorable external developments. The global economy was strong in 1999. The U.S. economy has been able to absorb a large amount of exports of the East Asian economies. The U.S. per capita GDP growth rates were 3.3-3.4 percent in 1998 and 1999 and jumped to 4.4 percent in 2000, which by far exceeded the average growth rate of 2.0 percent over the period from 1970 to 1995 . As we saw from the cross-country regressions in section 9.2, global economic growth has a strong impact on the postcrisis recovery, in particular in the early years following the crisis. The deterioration in terms of trade that precipitated the crisis reversed in 
1999. In particular, the increase in the prices of semiconductors helped to boost Korean, Malaysian, and Thai exports.

Macroeconomic Policy Adjustment. Concerning macroeconomic policy management, the swift change in policy stance toward expansion has supported a quick recovery of the crisis-hit economies. In Korea, relaxation of monetary and fiscal policy began around in April of 1998. A comparison of the turning points in the adjustment process measured by growth rates of the quarterly GDP with the timing of policy changes, broadly speaking, confirms that easing of monetary and fiscal policy has quickened the pace of recovery in both Thailand and Malaysia (figure 9.9). Thailand shifted to a modest relaxation of macroeconomic policy in June 1998, and its economy took off in the fourth quarter of the same year after zero growth in the preceding quarter. In particular, public consumption expenditure increased significantly in the latter half of 1998. It was not until the third quarter of 1998 - the end of August - that a relaxation of monetary and fiscal policy was announced in Malaysia, and its economy moved out of the trough one quarter later. In Indonesia, on the contrary, because of the continuing weakness of the rupiah, monetary policy remained contractionary until the second quarter of 1999. However, public consumption increased sharply in the third quarter of 1999. This expansion boosted output growth in 1999. In the Philippines, monetary policy was slightly contractionary over the postcrisis period, whereas public consumption expenditure has been growing since the first quarter of 1999.

The positive role of expansionary macroeconomic policies in postcrisis recovery raises the question of whether the initial tightening of monetary and fiscal policy was too harsh and maintained for too long and as a consequence deepened the crisis. In order to deal with the crisis itself - stopping bank runs, protecting the payment system, and stemming capital outflows - the IMF prescribed tight monetary policy together with fiscal austerity, which initially led to a sharp increase in interest rates. The contractionary monetary and fiscal policy has been criticized by many, including Radelet and Sachs (1998) and Feldstein (1998), as having been unnecessary because these countries were suffering from a liquidity problem. They imply that the traditional IMF prescriptions may have done more harm than good because they drove many highly leveraged but viable firms out of business, thereby deepening the downturn of the economy. The contribution of initial austerity from IMF programs remains controversial. On the other hand, it is quite clear that the swift change of macroeconomic policy stance toward an expansionary one helped these economies recover quickly. Fiscal policy had become contractionary immediately after the crisis, but it was reversed quickly to be expansionary. Change in monetary policy stance then followed. Once the depreciation of the currency was arrested and stability returned to the foreign exchange market, the authorities of the crisis 


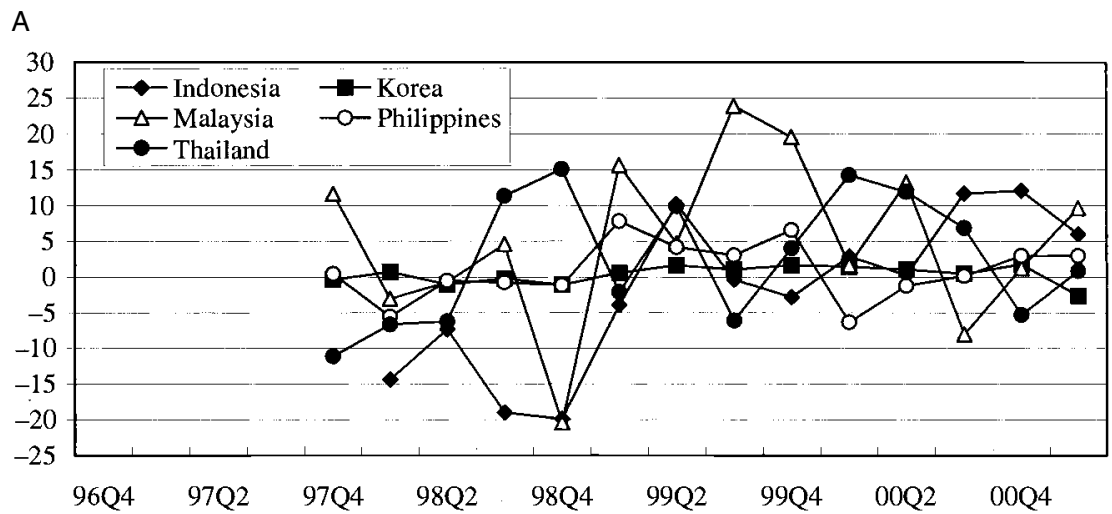

B

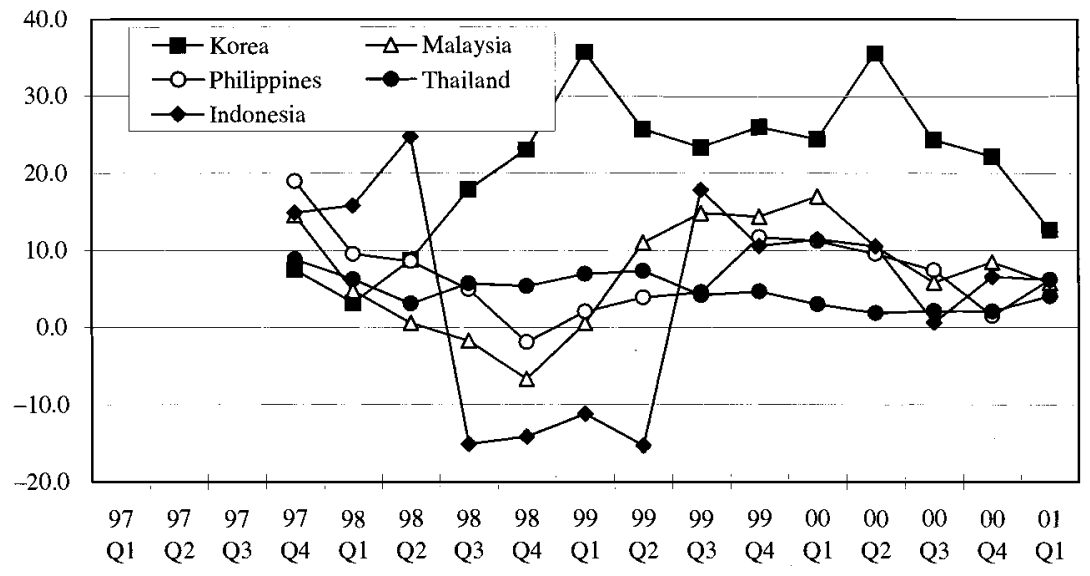

C

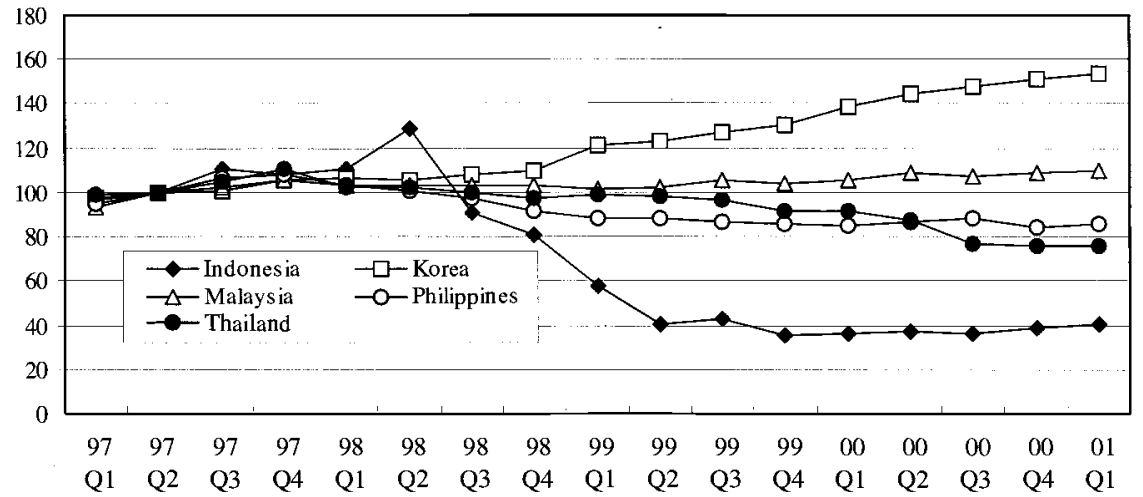

Fig. 9.9 Policy indicators in East Asia: $A$, real public consumption growth; $B$, real money supply growth; $C$, real credit $(1997: 2=100)$ 
countries were able to adjust gradually the interest rates downward and expand money supply.

\section{Panic and Balance Sheet Effects}

The contraction of real income in the East Asian countries that suffered the crisis was much larger, and the subsequent recovery of these countries has been much faster, than what can be predicted from the previous episodes of crisis elsewhere. There must be additional factors that have contributed to the deeper contraction and the quicker recovery in East Asia. We consider that the East Asian crisis has an aspect of a severe liquidity crisis caused by investors' panic. This nature of the crisis must have an important role in the macroeconomic adjustment during the crisis.

Panic and Spread of the Crisis. There is general agreement that a fixed peg to a currency basket dominated by the U.S. dollar when the current account was piling up deficits was one aspect of policy mismanagement that triggered the crisis in Thailand. In a recent paper, Williamson (2000) shows that had it been implementing a basket, band, and crawl (BBC) rule, Thailand might have staved off its crisis, because the country was suffering from a balance-of-payments crisis. However, the Thai crisis was contagious, as shown by Park and Song (2001a, b), and even a good exchange rate management using the BBC rule could not have saved other crisis victims like Indonesia and Korea from the contagion.

Although macroeconomic policies and economic fundamentals of Korea and Indonesia were regarded as being sound and credible, many foreign investors simply moved out of East Asian financial markets when they realized that most East Asian countries would suffer from macroeconomic and structural problems similar to those that were driving Thailand to the brink of debt default. With the withdrawal of foreign lenders and investors from the region, other East Asian countries experienced a sharp liquidity crisis and balance sheet problems associated with a large currency depreciation, causing a regionwide crisis explicable by a second- and third-generation model of the crisis. That is, the contagion of the Thai crisis set in motion a crisis characterized by self-fulfilling prophecy and balance sheet deterioration in other East Asian countries, which did not have a serious balance-ofpayment problem. Once hit by contagion, the BBC system was simply unable to stave off the crisis because the band could not be maintained.

Why did foreign portfolio investors panick so much and exhibit herd behavior? They initially moved into East Asia with large sums of money to be invested in all types of local securities and real assets with the mistaken notion that rapid growth in the region would be sustained or that their investments would be protected by government guarantees. Most of the foreign investors paid little attention to the structural problems of the financial and corporate sections that began to haunt East Asia before moving in. When 
these problems came to light in the midst of currency depreciation and interest rate increases, they were startled. The ensuing fear of losing their investments then drove them to a state of panic, and every investor was scrambling to reach the exit.

Thus, one critical factor that could explain both the initial sharper contraction and the faster recovery is related to changes in the expectations of foreign investors and both domestic households and firms on economic prospects of the crisis countries. When foreign investors began to lose confidence in East Asian economies, capital flows abruptly reversed. As shown in table 9.5, in 1997 private net capital flows reversed by $\$ 115$ billion (from a $\$ 120$ billion inflow in 1996 to a $\$ 5$ billion outflow). It is no wonder that this large-scale shift in financial inflows provoked deep contractions, huge depreciation, and financial embarrassment. The argument goes that once investors' panic calms down and foreign capital resumes inflow, the economy rebounds to its long-term trend.

Immediately after the crisis, there was rampant speculation that the crisis countries might not be able to avoid foreign debt default and hence might have to declare a debt moratorium. The international financial community, including international financial institutions, also did not hesitate to lay the blame on the East Asian countries for the crisis. With the emerging consensus that the crisis countries had profound problems that were more serious than had been realized before, the prospect for recovery in East Asia turned from bad to worse. Many were skeptical that these countries had the institutional capacity and political will to carry out the necessary structural reforms. Even if they had, the skeptics pointed out that these

Table 9.5 Capital Flows to the Five Asian Economies (in US Sbillions)

\begin{tabular}{lrrrrr}
\hline & 1996 & 1997 & 1998 & 1999 & $2000^{\mathrm{a}}$ \\
\hline External financing, net (A+B) & 118.6 & 39.5 & -15.2 & -4.9 & -1.2 \\
A. Private flows, net & 119.5 & 4.9 & -38.7 & -5.2 & -3.8 \\
$\quad$ Equity investment & 16.8 & 5.2 & 16.8 & 30.1 & 15.6 \\
Direct equity & 4.8 & 6.8 & 12.3 & 14.6 & 9.5 \\
Portfolio equity & 12.0 & -1.7 & 4.5 & 15.4 & 6.1 \\
Private creditors & 102.7 & -0.3 & -55.5 & -35.3 & -19.3 \\
Commercial banks & 69.6 & -17.4 & -48.8 & -29.3 & -15.3 \\
Nonbank private creditors & 33.2 & 17.2 & -6.7 & -6.0 & -4.1 \\
B. Official flows, net & -0.9 & 34.6 & 23.5 & 0.2 & 2.6 \\
International financial inst. & -1.9 & 22.7 & 19.7 & -4.6 & 2.5 \\
Bilateral creditors & 1.0 & 11.9 & 3.8 & 4.9 & 0.1 \\
\hline
\end{tabular}

Source: Institute for International Finance, January 2001.

Note: The five countries include South Korea, Indonesia, Thailand, Malaysia, and the Philippines.

${ }^{\text {aEstimated. }}$ 
crisis countries would take many years to put their houses in order. Under these circumstances, it is quite possible that the households and firms as well as foreign investors came to believe that the crisis was a permanent shock that would lead to a new equilibrium lower in terms of output and employment than when the crisis was seen as a temporary shock. This perception of permanency may have induced domestic consumers and investors to cut down their spending much more than they otherwise would have during the first six months of the crisis. However, the extensive criticism of East Asia diminished and gradually gave way to a more optimistic outlook for the crisis economies, and the realization that the crisis might be a temporary phenomenon started sinking into the minds of consumers and investors, thereby encouraging their spending.

In restoring the confidence of foreign investors, large support packages from the IMF made some contribution. The funding helped to reduce the short-term liquidity constraints of the economies and provide resources to stem the exchange rate depreciation. There were other turning points. Korea, for example, reached an agreement with its creditor in February 1998 to lengthen the maturities of the short-term foreign currency loans (Radelet and Sachs 1998). ${ }^{8}$ After the agreement was reached, at least some of foreign credit facilities, including trade credit, were restored. With this restoration of the credit linkage, the fear of the debt default abated considerably.

Balance Sheet Effects. A large decrease in aggregate investment demand during the crisis period suggests that corporate distress was one of the main factors responsible for the sharper contraction in output in East Asia. Structural weaknesses in the corporate and bank balance sheets were often pointed out as the main channel through which the effect of foreign disturbances was magnified in the East Asian crisis (Krugman 1999; Stone 2000).

The reversal of capital inflows combined with a sudden downward shift in expectation could lead to a sharp depreciation of the exchange rate. The large unexpected depreciation was much more disastrous in East Asia because most firms were highly leveraged. When the bulk of corporate debts is denominated in the U.S. dollar while revenues and assets are in local currency, the depreciation deteriorates the balance sheets of firms and inflicts large losses. Table 9.6 shows that foreign exchange losses of the Korean firms amounted to more than 17 trillion won, which was about 3.8 percent of GDP, in 1997. ${ }^{9}$ These losses, together with the increase in foreign debt financing costs, result in a decline in the present value of the equity of the corporate sector. Gray (1999) estimates that a 50 percent depreciation reduces

8. They did not do so voluntarily, but at the urging of the Group of Seven governments and the IMF, and only when they were convinced that they would be repaid with handsome returns.

9. According to Hahm and Mishkin (2000), the foreign liabilities accounted for about 16 percent in total corporate debt in 1997 in Korea. 
Table 9.6

Foreign Exchange Losses of the Korean Corporate Sector

(in billion won \%)

\begin{tabular}{lccr}
\hline & 1997 & 1998 & 1999 \\
\hline Gains on foreign exchange transactions (A) & $-2,692$ & -784 & 203 \\
Gains on foreign exchange valuation (B) & $-14,571$ & $-1,026$ & 2,533 \\
Total gains (A + B) & $-17,263$ & $-1,810$ & 2,736 \\
\% of total assets & -2.4 & -0.2 & 0.3 \\
$\%$ of GDP & -3.8 & -0.4 & 0.6 \\
\hline
\end{tabular}

Source: Authors' estimates based on the Bank of Korea Financial Statement Analysis.

Table 9.7

The Ratio of Foreign Liabilities to Foreign Assets of the Banking Sector (\%)

\begin{tabular}{lccccccccc}
\hline & Dec. & Mar. & June & Sept. & Dec. & Mar. & June & Sept. & Dec. \\
& 1996 & 1997 & 1997 & 1997 & 1997 & 1998 & 1998 & 1998 & 1998 \\
\hline Indonesia & 1.4 & 1.7 & 1.8 & 1.8 & 1.5 & 1.2 & 1.0 & 0.8 & 0.8 \\
Korea & 1.3 & 1.3 & 1.3 & 1.3 & 0.9 & 0.8 & 0.8 & 0.8 & 0.9 \\
Malaysia & 2.6 & 2.5 & 2.8 & 2.3 & 2.1 & 1.6 & 1.4 & 1.3 & 1.7 \\
The Philippines & 1.8 & 1.7 & 1.9 & 2.0 & 1.7 & 1.8 & 1.7 & 1.6 & 1.4 \\
Thailand & 6.9 & 7.3 & 6.8 & 5.5 & 4.7 & 4.2 & 3.2 & 2.5 & 2.3 \\
\hline
\end{tabular}

Source: Asian Development Bank, based on data from IMF, International Financial Statistics.

Note: Ratios calculated with gross foreign liabilities and assets of deposit money banks.

the equity value of Korean corporations by 9 percent and that of Indonesian corporations by 21 percent. The lower equity value leads to lower investment.

The balance sheets of the financial institutions were also very vulnerable to the currency depreciation. Because in East Asia banks had a large amount of foreign liabilities in their balance sheets, they suffered losses emanating from the currency mismatch. ${ }^{10}$ In June 1997 the ratio of foreign liabilities to foreign assets of the banking sector ranged from 1.3 in Korea to 6.8 in Thailand (table 9.7). Maturity mismatches also created another vulnerability. Korean data show that short-term foreign liabilities were more than two times larger than short-term foreign assets (table 9.8).

After banks and other nonbank financial institutions suffer a sharp decline in their profits and hence a substantial erosion of their capital base, they are downgraded by the rating agencies and often denied access to international financial markets. As experienced by many money-losing financial institutions in East Asia, foreign banks and other institutional investors simply cut the lines of credit they had offered through the interbank loan

10. In 1997 the foreign liabilities accounted for about 55 percent of banks' total liabilities in Korea, 27 percent in Thailand, and 15 percent in Indonesia (Asia Development Bank [ADB] 2000). 
Table 9.8

Foreign Assets and Liabilities Outstanding at Financial Institutions in Korea (in US \$billions)

\begin{tabular}{|c|c|c|c|c|c|c|c|c|c|}
\hline & $\begin{array}{l}\text { Dec. } \\
1996\end{array}$ & $\begin{array}{l}\text { Mar. } \\
1997\end{array}$ & $\begin{array}{l}\text { June } \\
1997\end{array}$ & $\begin{array}{l}\text { Sept. } \\
1997\end{array}$ & $\begin{array}{l}\text { Dec. } \\
1997\end{array}$ & $\begin{array}{l}\text { Mar. } \\
1998\end{array}$ & $\begin{array}{l}\text { June } \\
1998\end{array}$ & $\begin{array}{l}\text { Sept. } \\
1998\end{array}$ & $\begin{array}{l}\text { Dec. } \\
1998\end{array}$ \\
\hline \multicolumn{10}{|l|}{ Assets } \\
\hline Total & 67.2 & 70.4 & 72.1 & 72.0 & 72.0 & 70.5 & 71.2 & 68.1 & 63.9 \\
\hline Long-term & 30.6 & 33.2 & 33.2 & 32.5 & 27.3 & 25.9 & 27.1 & 26.0 & 24.7 \\
\hline ( $\%$ of total) & (46) & $(47)$ & $(46)$ & $(45)$ & (38) & (37) & $(38)$ & $(38)$ & (39) \\
\hline Short-term & 36.6 & 37.2 & 38.9 & 39.5 & 44.7 & 44.6 & 44.1 & 42.1 & 39.2 \\
\hline ( $\%$ of total) & (54) & $(53)$ & (54) & $(55)$ & $(62)$ & (63) & $(62)$ & $(62)$ & $(61)$ \\
\hline \multicolumn{10}{|l|}{ Liabilities } \\
\hline Total & 116.5 & 126.2 & 129.4 & 127.1 & 89.9 & 83.8 & 79.8 & 74.0 & 70.9 \\
\hline Long-term & 43.5 & 46.0 & 48.1 & 51.7 & 47.5 & 45.0 & 58.6 & 55.6 & 52.0 \\
\hline ( $\%$ of total) & (37) & (36) & (37) & (41) & (53) & (54) & (73) & (75) & (73) \\
\hline Short-term & 73.0 & 80.2 & 81.3 & 75.4 & 42.4 & 38.8 & 21.2 & 18.4 & 18.9 \\
\hline ( $\%$ of total) & (63) & $(64)$ & $(63)$ & $(59)$ & $(47)$ & (46) & $(27)$ & $(25)$ & (27) \\
\hline \multicolumn{10}{|l|}{ Net liabilities } \\
\hline Total & 49.3 & 55.8 & 57.3 & 55.1 & 17.9 & 13.3 & 8.6 & 5.9 & 7.0 \\
\hline Long-term & 12.9 & 12.8 & 14.9 & 19.2 & 20.2 & 19.1 & 31.5 & 29.6 & 27.3 \\
\hline Short-term & 36.4 & 43.0 & 42.4 & 35.9 & -2.3 & -5.8 & -22.9 & -23.7 & -20.3 \\
\hline \multicolumn{10}{|l|}{ Long-term asset/ } \\
\hline liabilities (\%) & 70.3 & 72.1 & 69 & 62.8 & 57.4 & 57.5 & 46.2 & 46.7 & 47.5 \\
\hline \multicolumn{10}{|l|}{ Short-term asset/ } \\
\hline liabilities (\%) & 50.1 & 46.3 & 47.8 & 52.3 & 105.4 & 114.9 & 208 & 228.8 & 207.4 \\
\hline
\end{tabular}

Source: Bank of Korea.

market and refused the rollover of short-term loans when their client institutions were in trouble. This refusal created a serious liquidity problem as well as balance sheet loss problems at the East Asian financial institutions. Faced with the liquidity problem, many banks and nonbank financial institutions had to reduce their supply of loans in both local and foreign currencies drastically even to their viable loan customers.

The mounting losses caused by the bank balance sheet deterioration is bound to increase the country risk premium of the crisis-hit countries. A rise in the country risk premium, in turn, pushes up the cost of capital and lowers the present value of the equity of the corporate sector. Gray (1999) estimates that an 8 percent temporary rise in the country risk premium for a year leads to a drop of 7 percent in the present value of corporate equity in Korea and 2 percent in Indonesia. ${ }^{11}$

An increase in the interest rate and currency depreciation together with other shocks can reduce the equity value of the corporate sector below a threshold that triggers widespread default. The risk of default was higher in

11. The high domestic interest rate, which aims at stemming rapid depreciation, has the same devastating effect on the value of corporate-sector equity and thus investment. 
East Asia, where firms were highly leveraged with a large amount of shortterm liabilities. The firms with a larger share of short-term debt faced more difficulties in financing and were unable to service their debts: bankruptcies soared, thereby magnifying the crisis.

In the recovery process, macroeconomic stability plays a crucial role for the normal operation of viable firms. Stabilization of the exchange rate and interest rate improves the equity value of the corporate sector and thus promotes investment. Improved confidence leads to an increase in spending. The restructuring of the corporate sector is necessary in order to reduce the vulnerability of the corporate sector and thus prevent the future crisis. However, in the short run, a quick recovery cannot be engineered unless there is resurgence of domestic demand.

\subsubsection{Structural Reform and Recovery ${ }^{12}$}

At the beginning of the crisis, there was widespread belief that the crisis countries' commitment to structural reforms would be critical to the recovery in East Asia. The reforms were expected to help East Asia emerge from the crisis with more stable, transparent, and efficient financial and corporate sectors. This expectation of reform espousing a market-oriented system would then improve long-term growth prospects and, at the same time, restore market confidence, thereby inducing the return of foreign lenders and investors to the region.

Three years into the reform process, the crisis countries have accomplished a great deal in improving the soundness and profitability of financial institutions and alleviating corporate distress. The World Bank (2000) argues that "assertive structural adjustment helped restore credit flows and boosted consumer and investor confidence" (7). However, it is not clear whether and to what extent financial and corporate restructuring has contributed to the ongoing recovery. Most of the serious structural problems that were identified as the major causes of the crisis in Indonesia, Korea, Malaysia, and Thailand could not have been resolved over a span of two years. In fact, banks are still holding in their balance sheets a large volume of nonperforming loans and remain undercapitalized in all four countries. Many corporations in the region are still unable to service their debts. As for institutional reform, new banking and accounting standards, disclosure requirements, and rules for corporate governance have been introduced, but they are not rigorously enforced. It will take many years for the new system to take root.

Because the crisis countries are not even halfway to restructuring their financial institutions and corporations, it would be presumptuous to argue that the reform efforts have established a foundation for sustainable growth in East Asia. Nor would it be correct to assert that the gain in efficiency 
through the restructuring, which is difficult to measure at this stage, has been one of the principal factors driving the recovery. The improvement in efficiency is likely to be realized and translated into high growth over a longer period of time, certainly longer than two years.

The available pieces of evidence also do not support the contention that the market-oriented reform has contributed to restoring market confidence in the East Asian crisis countries; it certainly did not appear to have done so during the first two years of the crisis. International credit rating agencies report that the reforms in the banking sector in the crisis countries have not gone through enough to ensure that these economies would be able to forestall another financial crisis. Only toward the end of 1999 did Moody's and Standard \& Poor's upgrade the sovereign credit ratings of Korea and Malaysia to the lowest investment grade from the speculation grade. By that time, the recovery was in full swing in East Asia. Journalistic accounts have abounded with similar concerns and continued to raise doubts regarding the effectiveness of the reform in the crisis countries. Under these circumstances, most foreign investors would find it risky to return to the crisis countries, but they have. Many of the foreign investors appear to have been lured back by the rapid recovery and substantial improvements in external liquidity resulting from large surpluses on the current account.

Reflecting recovery rather than ratings improvement, capital inflows in East Asia have been rising. Because policy changes and structural reforms are subject to many uncertainties and require a long period of time to take effect, international banks and global institutional lenders do not seem to have either the patience or ability to monitor and assess the effects of structural reforms. This is particularly true when they are preoccupied with the short-term performance of their portfolios.

\subsubsection{Differences in Postcrisis Performance among the Asian Countries}

The five Asian countries most affected by the Asian financial crisis showed the speedy recovery that was faster than anyone had expected. However, the extent of the recovery from the crisis differed among the five countries. By the end of 1999 only Korea had surpassed its precrisis peak level of GDP. Malaysia and the Philippines did it later in 2000, whereas Thailand and Indonesia still need another year or so to recover to their precrisis output level.

Table 9.4 indicates that the difference in the postcrisis recovery in 1999 reflects mainly the difference in the performance of investment and export growth among the Asian countries. Although the annual growth rate of export in 1999 amounted to 16.4 percent in Korea, 13.8 percent in Malaysia, and 8.9 percent in Thailand, it was -32.1 percent in Indonesia. After investment ratios had dropped sharply in the five Asian countries in 1998 due to the crisis, they showed slow recovery in 1999 in both Korea and 
Malaysia. By contrast, in the other three Asian countries investment ratios contracted further in 1999.

The investment contractions reflect the significant distress in both the corporate and financial sectors. The financial crisis caused deterioration of the firms' balance sheets. Then the deterioration of the balance sheets of firms caused a massive accumulation of nonperforming loans at banks and other nonbank financial institutions. The accumulation of bad loans cut into profits and consequently decreased the equity value of the financial institutions. Decapitalized financial institutions, as a result of the mounting losses, were forced to curtail their lending to both viable and nonviable firms, thereby exacerbating the downturn of investment.

In the bank-oriented financial system that characterizes the financial structure of the crisis-hit countries in East Asia, the repercussion of the bank failure is much more pervasive and felt throughout the economy. Because of their dominance, therefore, banks are likely to bring down many viable firms when they are not able to function as intermediary.

Data show that the investment and output contractions in the Asian countries are closely associated with the sluggish bank lending. Although monetary supply began to expand in 1999 for the five Asian economies, the supply of bank credit in real terms continued to slow down in three of them-Indonesia, Thailand, and the Philippines (panels B and C of figure 9.9). In fact, more than three years after the crisis, real credit supply remains below the precrisis level yet in those three countries. The investment ratio recovered most quickly in Korea, where real credit increased at the highest rate over the postcrisis period.

\subsection{Prospects for Long-Term Growth in East Asia}

As the recovery continues in East Asia, there is a growing hope that these economies will be able to return to the precrisis level of robust growth. In this section, we make an assessment of the long-term growth prospects for East Asia.

\subsubsection{Impacts of a Currency Crisis on Long-Term Growth}

In this section we investigate the impact of a currency crisis on long-run growth based on a cross-country regression framework. We control all important growth determinants and then examine whether a currency crisis has had any independent impact on GDP growth in the long run.

A wide variety of external environment and policy variables will affect growth prospects by changing the long-run potential income and the rate of productivity growth. Basing our calculations on the results from previous empirical research, we consider the following variables as the important determinants of long-run per capita income growth: (a) initial income; (b) hu- 
Table 9.9

Long-Run Impact of Currency Crisis on Per Capita Growth Rate

\begin{tabular}{lcc}
\hline & \multicolumn{2}{c}{ Seemingly Unrelated Regression } \\
\cline { 2 - 3 } Estimation Method & Equation (1) & Equation (2) \\
\hline Initial GDP per capita, log & -1.965 & -1.975 \\
& $(0.360)$ & $(0.365)$ \\
Years of schooling & 0.350 & 0.357 \\
& $(0.246)$ & $(0.247)$ \\
Investment rate & 0.084 & 0.085 \\
& $(0.033)$ & $(0.032)$ \\
Terms of trade change, \% per annum & 0.084 & 0.086 \\
& $(0.036)$ & $(0.037)$ \\
Government consumption, \% in GDP & -0.139 & -0.140 \\
& $(0.032)$ & $(0.032)$ \\
Rule-of-law index & 1.212 & 1.195 \\
& $(0.830)$ & $(0.829)$ \\
Openness, 1 = most open & 2.726 & 2.708 \\
& $(0.482)$ & $(0.485)$ \\
Currency crises, no. in previous decade & 0.043 & 0.211 \\
& $(0.033)$ & $(0.436)$ \\
Currency crises with IMF program, no. & & -0.386 \\
in previous decade & & $(0.670)$ \\
$R^{2}$ & $0.54,0.37$ & $0.54,0.37$ \\
$N$ & 84,82 & 84,82 \\
\hline
\end{tabular}

Notes: The system has two equations, where the dependent variables are the growth rate of real per capita GDP for each of the two periods: $1975-85$ and 1985-95. The estimations use the SUR (seemingly unrelated) estimation technique, which allows the error term to be correlated across the two periods and to have a different variance in each period. Each equation is allowed to have a different constant term (not reported). Standard errors are shown in parentheses. The $R$ values and the number of observations apply to each period separately.

man resources, (c) investment rate; (d) exogenous shock (terms of trade changes), and (d) institutions and policy variables (government consumption, rule of law, and openness). ${ }^{13}$ For the measure of human capital stock, we use the average years of secondary and higher school education for the population aged 15 and over, available from Barro and Lee (2001). The ruleof-law index is a measure for the quality of institutions, which is based on the evaluation by international consulting firms that give advice to international investors. The openness measure is based on Sachs and Warner (1995). This index is calculated as the fraction of years during the period in which the country was considered to be open to trade and thus sufficiently integrated with the global economy. The evaluation of the country's openness is made on the basis of four dimensions of trade policy: average tariff rates, quotas and licensing, export taxes, and black market exchange rate premium.

Table 9.9 presents the results of regression for per capita real GDP

13. Our specification closely follows Barro (1997) in selecting the explanatory variables. 
growth rate using the explanatory variables just described. The data are a panel set of cross-country data over the two decades 1975-85 and 1985-95. The system of two equations is estimated by a SUR technique, which allows for the correlation of the errors across the equations.

The regressions show that most of the controlling variables are the significant determinants of long-term growth. For instance, the coefficient on the $\log$ value of initial GDP is highly significant. Thus, it provides strong evidence for conditional convergence: That is, a poor country with a lower initial income level grows faster when the variables influencing the steady-state level of income are controlled. Specifically, the coefficient in column (1) of table 9.9 implies that a country at half the income level of another country grows by 1.4 percentage points $[=2.04 \% * \ln (2)]$ faster than the richer country.

We add to the regression a variable that measures the occurrence of currency crises. The variable is constructed with the number of currency crises that each country experienced during the past decade. We have used the number of crises over the period 1970-75 for the first equation and the period 1975-85 for the second equation. Thus, we test whether an experience of a currency crisis can have an impact on growth in the next decade. The estimated coefficient turns out to be statistically insignificant, implying that there is no direct impact of currency crises on growth in the long run. In column (2) of the regression, we add another variable that represents the number of currency crises with the IMF program participation. We also found no significance for this variable.

Although there is no direct impact of a currency crisis on long-run growth, it would be possible that a currency crisis or IMF program can have an indirect impact on long-run growth by influencing the controlling variables. For instance, if the investment ratio becomes permanently lowered by the postcrisis stabilization program in the crisis-hit countries, it would have a negative impact on growth in the long run. On the contrary, if the IMF structural reform improves the quality of institutions, then a currency crisis with IMF program participation can have a positive impact on growth.

\subsubsection{Sustainability of East Asian Growth}

The quick turnaround of the Asian economy from the 1997 crisis has brightened the region's economic prospects. Despite the impressive record of the recovery, however, not everyone is sanguine about East Asia's future prospects. The World Bank and the IMF, for example, are not optimistic about the prospects of these countries' sustaining the ongoing recovery, largely because weaknesses of financial institutions and balance sheet problems of corporations still remain unresolved in the region.

The macroeconomic performance of the crisis countries in the next few years will provide important clues to the question of whether these countries will be able to return to the pre-crisis trend rate of growth. Up to the 
present, the pattern of recovery in East Asia has been quite similar to that of Mexico after its crisis in 1994.

Although the financial crisis of 1997 abruptly brought a halt to Asia's period of robust growth, there was little in Asia's fundamentals that inevitably led to the crisis. The key to the Asian crisis was too much short-term capital flowing into weak and undersupervised financial systems. This suggests that, with better financial management and a return to the core policies that resulted in rapid growth, the East Asian economies can again return to sustained growth (Radelet, Sachs, and Lee 2001). The major factors that brought the relatively high growth in East Asia were high rates of saving, good human resources, trade openness, and maintenance of good institutions. In terms of these fundamentals, East Asia still keeps strong potential for a sustained growth.

However, in the long term, the growth rate will be lower than the previous precrisis average of 7 percent. The convergence factor, which was found to be quite strong in the cross-country growth regression in the last section, implies that the faster growth in the last decades in itself will force the East Asian economies to grow at a slower pace in the next decade. That is, the East Asian countries now have a much smaller gap in reproducible (physical and human) capital and technical efficiency from their long-run potential levels than they had in the last decades. Hence, the East Asian economies will face a smaller chance for rapid catching up, via high rates of capital accumulation as well as the diffusion of technology from more technically advanced economies in the next decade, and will inevitably become adjusted to a lower growth path.

The coefficient in the cross-country growth regressions implies that the convergence factor alone makes the Asian economies grow by about 1.5 percentage points slower over the next decade, compared to the last decades, in which they had started with less than one half of the current income. Hence, unless the economies could achieve substantial improvements in other fundamental factors, such as quality of institutions, they would grow at the range of 5 percent per year in GDP.

\subsection{Concluding Remarks}

The contraction of real income in the East Asian countries that suffered the crisis that erupted in 1997 was much larger, and the subsequent recovery of these countries has been much faster, than what can be predicted from the previous episodes of crisis elsewhere. The purpose of this paper has been to identify some of the factors that may explain the severity of and rapid recovery from the crisis. According to our empirical examination of macroeconomic developments following the crisis in East Asia, including a V-type adjustment of real GDP growth, a large real depreciation, expansionary monetary and fiscal policy, and an improvement in the global economic environment have been responsible for the upturn of the crisis-hit 
countries. In this sense, the East Asian process of adjustment is not much different from the stylized pattern observed from the previous 176 currency crisis episodes over the period from 1970 to 1995 . However, the stylized pattern of adjustment cannot explain why the crisis was more severe, and the recovery has been much faster, than what was expected from the previous experiences of crisis. This study argues that the East Asian financial upheaval was in large measure a liquidity crisis caused by investors' panic. Once the liquidity constraint was eased, as it was during the first half of 1998, domestic demand has since surged again, and the crisis countries have been able to move toward the precrisis path of growth.

\section{References}

Aghion, Philippe, Philippe Bacchetta, and Abhijit Banerjee. 2000. Currency crises and monetary policy in an economy with credit constraints. Harvard University, Department of Economics. Working Paper.

Asia Development Bank. (ADB). 2000. Asian recovery report 2000. Manila, the Philippines: Asia Development Bank.

Barro, Robert. 1997. Determinants of economic growth: A cross-country empirical study. Cambridge: MIT Press.

Barro, Robert, and Jong-Wha Lee. 2001. International data on educational attainment: Updates and implications. Oxford Economic Papers 53 (3): 241-63.

Conway, Patrick. 1994. IMF lending programs: Participation and impact. Journal of Development Economics 45:365-91

Feldstein, Martin. 1998. Refocusing the IMF. Foreign Affairs 77:20-33.

Frankel, Jeffrey A., and Andrew K. Rose. 1996. Currency crashes in emerging markets: An empirical treatment. Journal of International Economics 41:351-66.

Goldfajn, Ilan, and Poonam Gupta. 1999. Does monetary policy stabilize the exchange rate following currency crisis? IMF Working Paper no. WP/99/42. Washington, D.C.: International Monetary Fund.

Gray, Dale. 1999. Assessment of corporate sector value and vulnerability: Links to exchange rate and financial crises. World Bank Technical Paper no. 455. Washington, D.C.: World Bank.

Gupta, Poonam, Deepak Mishra, and Ratna Sahay. 2000. Output response during currency crises. Washington, D.C.: International Monetary Fund and World Bank. Mimeograph.

Hahm, Joon-Ho, and Frederic Mishkin. 2000. Causes of the Korean financial crisis: Lessons for policy. NBER Working Paper no. 7483. Cambridge, Mass.: National Bureau of Economic Research.

Haque, Nadeem UI, and Mohsin S. Kahn. 1998. Do IMF-supported programs work? A survey of the cross-country empirical evidence. IMF Working Paper no. WP/98/169. Washington, D.C.: International Monetary Fund.

Hong, Kiseok, and Aaron Tornell. 1999. Post-crisis development of Asia. Korea Development Institute. Mimeograph.

Kaminsky, Graciela, and Carmen M. Reinhart. 1999. The twin crises: The causes of banking and balance-of-payments problems. American Economic Review 89 (3): 473-500.

Krugman, Paul. 1999. Balance sheets, the transfer problem, and financial crises. In 
International finance and financial crises: Essays in honor of Robert P. Flood, Jr., ed. Robert P. Flood, Andrew Rose, Assaf Razin, and Peter Isard, 31-56. Norwell, Mass.: Kluwer Academic.

Lee, Jong-Wha, Kiseok Hong, and Changyong Rhee. 2001. The macroeconomic adjustment during the currency crises. Kyung Je Hak Yon Ku 49 (2): 227-53.

Lee, Jong-Wha, and Changyong Rhee. 2002. Macroeconomic impacts of the Korean financial crisis: Comparison with the cross-country patterns. World Economy 25(4): 539-62.

Milesi-Ferreti, Gian Maria, and Assaf Razin. 1998. Current account reversal and currency crises: Empirical regularities. IMF Working Paper no. WP/98/89. Washington, D.C.: International Monetary Fund.

Park, Yung Chul. 2001a. East Asian dilemma: Restructuring out or growing out? Essay in International Economics no. 223. Princeton, N.J.: Princeton University.

- 2001b. A post crisis paradigm of development for East Asia: Governance, markets, and institutions. Korea University, Department of Economics. Mimeograph.

Park, Yung Chul, and Chi-Young Song. 2001a. Financial contagion in the East Asian crisis: With special reference to the Republic of Korea. In International financial contagion, ed. Stijn Classens and Kristin Forbes, 241-65. Norwell, Mass.: Kluwer Academic.

-2001b. Institutional investors, trade linkage, macroeconomic similarities, and the contagious Thai crisis. The Journal of Japanese and International Economies 15:199-224.

Przeworski, Adam, and James R. Vreeland. 2000. The effect of IMF programs on economic growth. Journal of Development Economics 62:385-421.

Radelet, Steven, and Jeffrey Sachs. 1998. The East Asian financial crisis: Diagnosis, remedies, prospects. Brookings Papers on Economic Activity, Issue no. 1:1-74. Washington, D.C.: Brookings Institution.

Radelet, Steven, Jeffrey Sachs, and Jong-Wha Lee. 2001. Determinants and prospects of economic growth in Asia. International Economic Journal 15 (3): 1-30.

Sachs, Jeffrey, Aron Tornell, and Andrei Velasco. 1996. The collapse of the Mexican peso: What have we learned? Economic Policy 22:13-56.

Sachs, Jeffrey, and Andrew Warner. 1995. Economic Reform and the process of global integration. Brookings Papers on Economic Activity, Issue no. 1:1-118. Washington, D.C.: Brookings Institution.

Stone, Mark. 2000. The corporate sector dynamics of systemic financial crises. IMF Working Paper no. WP/00/114. Washington, D.C.: International Monetary Fund.

Williamson, John. 2000. Exchange-rate regimes for East Asia: Reviving the intermediate option. Policy Analysis in International Economics, no. 60. Washington, D.C.: Institute for International Economics.

\section{Comment Richard Portes}

This paper examines two main issues: First, there is an analysis of crosscountry patterns of adjustment in currency crises. This is a "cross-

Richard Portes is professor of economics at London Business School and a research associate of the National Bureau of Economic Research. 
sectional event study," as in Eichengreen and Rose (chap. 3 in this volume). Second, the authors discuss the pattern of recovery in East Asia during 1999-2000. At times, the reader may feel that these are two separate papers. The graphs look the same, although the first set use annual data, whereas those on the recovery use quarterly figures; but the style and method of analysis differ considerably. There is not much connection between the two; the main link originally seemed to be the role of International Monetary Fund (IMF) programs, but they do not in fact appear in the discussion of East Asia.

In looking at the cross-country patterns, the authors identify 160 crisis episodes. They define a crisis only in terms of exchange rate depreciation (ignoring, for example, loss of reserves in cases in which the currency is attacked and successfully defended, as well as banking or debt crises). They distinguish between countries that adopt IMF programs to deal with the crisis and those that do not.

This distinction makes no difference to the behavior of output in the period leading up to the crisis and thereafter. The crisis countries' growth rates fall from $t-4$ to $t-1$, then rise in $t$ - both for countries that adopt IMF programs and for the full sample. Here we may draw a contrast with Eichengreen and Rose: their output loss effect occurs in $t$ and $t+1$. The reason for this quite significant difference between the two papers is not clear.

The authors do find differences between IMF-program countries and others: the V-shaped behavior of output is stronger for the former, which make a quicker recovery from a deeper recession. They also exhibit a stronger fall in the share of investment (an effect that lasts through $t+5$ ), a sharper V-shape for the share of imports, and a substantially sharper fall of public consumption, real M2 and bank credit.

What does all this mean? The puzzle is accentuated by the finding that the IMF program dummy is insignificant in the postcrisis recovery regressions! There are some similarities in postcrisis behavior between those countries with programs and the rest: the real exchange rate behaves similarly; the import share is identical in $t+5$; and so is the export share (a striking statistical artifact). That, however, is all. The puzzle is not resolved, and equations of the type used in the paper to describe the recovery period are unlikely ever to get us very far. They use a few endogenous variables (investment, real M2, the real exchange rate, public consumption) on the right-hand side, and there is no underlying structure.

The finding that poorer countries recover more strongly from crises is interesting. It is consistent with the conjecture that crises in general have much more limited effects on rich countries - in particular, the conjecture that if Eichengreen and Rose were to look at Organization for Economic Cooperation and Development (OECD) countries (say) separately, they would not exhibit the output loss effect from crisis that is the key finding of their paper. 
When we turn to the specific episode of East Asia - the crisis of 1997-98 and the recovery of 1999-2000 - the volatility of external financing is the first striking phenomenon. Moreover, annual data very much understate the violence of the shock: for example, Korea experienced an outflow of \$27 billion in 1997:3-1997:4, including \$19 billion in 1997:4 alone. The commercial banks have been withdrawing funds continuously from the region since mid-1997, including 2000. In the crisis period itself, 1997-98, the international financial institutions put in $\$ 42$ billion, while the banks withdrew $\$ 66$ billion. Of course, if the international financial institutions had not injected so much, the banks might not have been able to take it out.

The authors' characterization of the postcrisis period might be summarized as "V for victory": a combination of policies and underlying positive fundamentals permitted a quick and strong recovery. The initial contraction is attributed mainly to a fall in investment, with fairly stable private consumption. The recovery appears to have come mainly from net exports, due to a big real depreciation in very open economies, with some stimulus from public investment in Korea and Malaysia and fairly early relaxation of monetary and fiscal policies. The argument is essentially that the stress on structural reforms is misplaced - or, at least, that such reforms could not have been the source of recovery, because they could not have had such rapid effects. The authors maintain that the underlying fundamentals of the crisis economies were in fact stronger than critics believed, so that with better financial management and a macro stimulus, they were able fairly easily to return to the precrisis growth path.

In this view, restructuring and reform was much less essential than the IMF and many observers contended. The supply side was flexible enough to respond despite the unfavorable balance sheet effects of exchange rate depreciation. If the underlying supply side is strong, then it's all a question of demand, and depreciation in the context of the generally favorable external environment of 1998-2000, together with an early switch to expansionary policies, gave the necessary demand-side stimulus. This view is consistent with the absence of identifiable effects from IMF programs. I find it attractive, although I do not think the paper gives very convincing support for it.

\section{Discussion Summary}

James Levinsohn suggested that selection bias might be an explanation for the insignificant IMF coefficients the authors found. Just as higher mortality rates for patients undergoing treatment in the Mayo clinic are found, the authors' regression understates the positive effect of the IMF because only the "sickest" cases receive a program. 
Gian Maria Milesi-Ferretti referred to a paper coauthored with Assaf Razin in which they studied the evolution of output growth following crises but attempted to control for precrisis economic conditions, rather than postcrisis outcomes, so as to limit endogeneity problems. He also observed that the authors' definition of crises identifies many hyperinflation episodes, such as those in Argentina and Brazil, during which the nominal exchange rate depreciates very rapidly. These events are not meaningful currency crises, he argued. Peter B. Kenen said that the role of net exports seems central to the argument, but in most cases the effect came from a contraction of imports rather than an expansion of exports. Thus, it could not have been a stimulus to recovery. Second, the work does not account for the fact that the IMF program might affect some of the right-hand-side dummy variables.

Edwin M. Truman stated that there were warnings about the coming crisis, although they were not as dire as the crisis turned out to be. German banks were, for example, not allowed to treat Korea as an OECD country under the Basel capital requirements, as was also the case for Mexico. Also, he argued, one should try to match countries with their initial conditions in order to compare growth rates productively.

Nouriel Roubini argued that there is too much emphasis on illiquidity in the authors' description of Korea. He supported his argument with details such as the fact that seven out of the thirty biggest chaebol went into bankruptcy in 1997 before the crisis. So, he concluded, there were substantial problems in the Korean economy besides illiquidity and besides the oftencited problems, such as crony capitalism. He explained the recovery by the amount of reform undertaken. Thus, the rapid Korean recovery is explained by the deeper corporate restructuring undertaken and not by the expansionary monetary and fiscal policy adopted by all of the crisis countries. Korea reformed more than Thailand, which reformed more than Indonesia; Japan did not reform at all, and these observations explain their respective rates of recovery.

Martin Feldstein remarked that the regressions pool all data from 1975 but both crises and IMF programs changed a lot over that period. He also observed that aside from a description of the recovery of growth rates there is no discussion of levels. It therefore remains unclear whether there was overshooting so the loss in output was permanent. Besides that, he observed that many banks and corporations were taken over by the government and that this is not reform: these institutions now got their financing from the government. These institutions received liquidity by being taken over, but this is not restructuring. The crucial stage, and possibly the big surprise, will be when the government divests itself of these institutions.

William Easterly argued that any conclusions with regard to the IMF dummy in the regressions are flawed, because some of the right-hand-side variables are the policy variables, which the IMF tries to affect. Thus, when these are controlled for, the IMF's effect is not evaluated fairly. 
Michael P. Dooley noted that the reversal in the current account is a solution to the external problem because it pays off the foreign creditors, but it still does not generate the internal transfer to cover the loss in the banking system, and that is where there are potential output effects. There still has to be a big redistribution from taxpayers to the government to privatize the banks. Without that, he doubted whether there will be recovery of output growth.

Morris Goldstein observed that even when self-selection bias is accounted for, as in the paper by Michael Hutchison, there still does not seem to be any significant effect of the IMF on growth, or maybe only a small temporary negative one. It still does not generate wonderful positive effects for the IMF.

Yung Chul Park responded that Kenen's point is right: the paper should differentiate between contraction of imports and expansion of exports.

It is not fair to say, he argued, that the international community knew about these structural problems - crony capitalism, moral hazard, and the like. Moreover, he noted that he has a record of many international investors who were willing to extend credit lines at the time. The bankruptcies were partly a result of the restructuring implemented at the time. He emphasized that these structural problems did not trigger the crisis, and this supports the liquidity argument.

In response to Dooley's comment, he observed that Korea now has the resources for domestic restructuring. The problem remains the political will to undertake them. It is very hard to restructure and reallocate resources without creating serious social dissention in a democratic society.

Jong-Wha Lee agreed that it is hard to isolate the net effect of IMF program. The regressions controlled only for precrisis GDP level and growth rate, he said, but these are assumed to proxy for many other variables. In response to Feldstein, he also observed that recovery was indeed fast and growth rates were overshooting for some countries, including Korea, and that GDP levels did recover. 